Currency excess returns and global downside market risk

Victoria Galsband and Thomas Nitschka

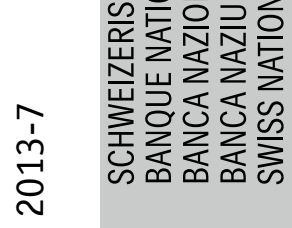

$\frac{0}{10}$

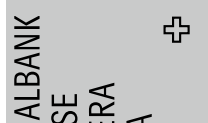

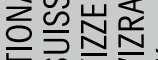

它的领

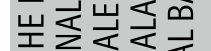

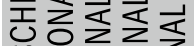


The views expressed in this paper are those of the author(s) and do not necessarily represent those of the Swiss National Bank. Working Papers describe research in progress. Their aim is to elicit comments and to further debate.

\section{Copyright ${ }^{\odot}$}

The Swiss National Bank (SNB) respects all third-party rights, in particular rights relating to works protected by copyright (information or data, wordings and depictions, to the extent that these are of an individual character). SNB publications containing a reference to a copyright ( $\odot$ Swiss National Bank/SNB, Zurich/year, or similar) may, under copyright law, only be used (reproduced, used via the internet, etc.) for non-commercial purposes and provided that the source is mentioned. Their use for commercial purposes is only permitted with the prior express consent of the SNB.

General information and data published without reference to a copyright may be used without mentioning the source.

To the extent that the information and data clearly derive from outside sources, the users of such information and data are obliged to respect any existing copyrights and to obtain the right of use from the relevant outside source themselves.

\section{Limitation of liability}

The SNB accepts no responsibility for any information it provides. Under no circumstances will it accept any liability for losses or damage which may result from the use of such information. This limitation of liability applies, in particular, to the topicality, accuracy, validity and availability of the information.

ISSN 1660-7716 (printed version)

ISSN 1660-7724 (online version)

๑ 2013 by Swiss National Bank, Börsenstrasse 15, P.0. Box, CH-8022 Zurich 


\title{
Currency excess returns and global downside market risk
}

\author{
Victoria Galsband* \\ Deutsche Bundesbank
}

\author{
Thomas Nitschka \\ Swiss National Bank
}

First version: 13 May 2012

This version: 14 May 2013

\begin{abstract}
We take the perspective of a US investor to assess cross-sectional differences in 19 bilateral, conditional currency excess returns in an empirical model that distinguishes between USspecific and global risks, conditional on US bull (upside) or bear (downside) markets. At first glance, our results suggest that global downside risk is compensated in average bilateral currency excess returns. Further analysis, however, reveals that downside risk and financial market volatility exposures are closely related. Moreover, the downside risk evidence is mostly driven by emerging markets' currencies. We conclude that downside risk models do not fully address the issue of foreign currency excess returns being largely unrelated to standard risk factors.
\end{abstract}

JEL: F31, G15

Keywords: CAPM, downside risk, exchange rate, forward premium puzzle, uncovered interest rate parity, upside risk

\footnotetext{
*E-mail: victoria.galsband@,bundesbank.de; thomas.nitschka@snb.ch

We gratefully acknowledge comments and suggestions by Katrin Assenmacher and an anonymous referee of the SNB working paper series. This paper also benefitted from comments by participants in the SNB Brown Bag Seminar and the SFB 649 "Risk Preferences and Decisions under Uncertainty" Workshop at Humboldt University Berlin. The views expressed in this paper do not necessarily reflect the view of the Deutsche Bundesbank or the Swiss National Bank. Any errors and omissions are our own.
} 


\section{$1 \quad$ Introduction}

The difference between current forward and spot exchange rates, i.e. the forward discount, should be a good predictor of future exchange rate movements according to the uncovered interest rate parity condition (UIP). However, a wealth of studies initiated by Tryon (1979), Hansen and Hodrick (1980) and Fama (1984) find that exchange rate changes do not follow forward discounts or, equivalently, interest rate differentials. Regressing realized spot exchange rate changes on the previous period's forward discounts typically produces negative or insignificant point estimates. ${ }^{1}$ This amounts to saying that currencies with a forward discount tend to depreciate while the forward discount, in general, should predict an appreciation. This ex post deviation from the UIP, also known as the "forward premium puzzle", can be potentially rationalized by means of a time-varying risk premium that investors demand on foreign currency denominated investments. ${ }^{2}$

Risk premia on foreign currencies that lead to violations of the UIP might reflect crash risk or rare events (e.g. Brunnermeier et al., 2009; Farhi et al., 2013; Farhi and Garbaix, 2011) or differences in the sensitivity of currencies to systematic risk factors (e.g. Ang and Chen, 2010; Christiansen et al., 2011; Lustig and Verdelhan, 2006, 2007; Lustig et al., 2011; Menkhoff et al., 2012a; Verdelhan, 2010, 2012).

However, the literature explaining ex post deviations from the UIP with exposures to systematic risk factors faces criticisms on three main grounds. First, it typically relies on the formation of currency portfolios to document the empirical relation between systematic risk factors and deviations from the UIP condition in the cross-section (e.g. Ang and Chen, 2010; Galsband and Nitschka, 2013; Lustig and Verdelhan, 2007, Lustig et al., 2011; Menkhoff et

\footnotetext{
${ }^{1}$ Bansal and Dahlquist (2000) show that this observation does not pertain to high inflation countries. Meredith and Chinn (2005) use long-term government bond yields as proxies for risk-free rates to evaluate the explanatory power of long-term yield differentials for exchange rate changes at long horizons. They find that the UIP holds at time horizons of 5 years or beyond. Lothian and $\mathrm{Wu}$ (2005) show that the UIP holds in a long sample period until the 1980s. Huisman et al. (1998) use a panel setup to show that the UIP is violated but with significant, non-negative regression coefficients.

${ }^{2}$ Backus et al. (2010) provide a theoretical model in which monetary policy, central banks in big closed and small open economies following different Taylor Rules, could generate violations of the UIP. Burnside et al. (2011) argue that peso problems account for violations from the UIP.
} 
al., 2012; Rafferty, 2011). Second, general, empirical pricing models that are successful in explaining excess returns on currency portfolios typically imply implausible values of risk aversion. For example, the consumption-based models examined in Lustig and Verdelhan (2007) rationalize the cross-sectional dispersion in currency portfolio returns only with implied risk aversion parameter values around 100. A similar value of risk aversion is needed in an intertemporal CAPM setting to explain currency portfolio returns (Galsband and Nitschka, 2013). Third, confronted with bilateral currency excess returns, the most successful empirical currency pricing models employ rather ad hoc risk factors. Examples include the "carry trade factor", i.e. the return differential on high and low forward discount sorted currency portfolios, introduced by Lustig et al. (2011) or a measure of global volatility on foreign exchange markets (Menkhoff et al., 2012a). More general proxies of systematic risk cannot account for (bilateral) currency excess returns well (Burnside et al., 2011; Burnside, 2011).

We try to address these concerns by proposing a simple extension of the standard empirical version of the CAPM. The CAPM appears to be an appropriate starting point to address the concern regarding investors' risk aversion as it can be derived under the assumption of a logarithmic utility function, such that the relative risk aversion parameter is restricted to be close to one. Our empirical CAPM version has two key non-standard features. First, it takes into account country-specific and global market risks from a US investor's point of view. Second, it distinguishes between upside and downside risks in the two market return components and allows thus for loss aversion in individual preferences. Upside risk is the sensitivity to the market excess return when the latter is positive. Downside risk is accordingly measured by the sensitivity to the market excess return when the latter is negative.

What motivates these model features? Recent papers have shown that downside risk models are helpful in explaining average returns on stock markets (Ang et al., 2006; Botshekan et al., 
2012; Galsband, 2012). The basic rationale for the success of these downside risk models is investors' loss aversion (Kahnemann and Tversky, 1979; Gul, 1991). In such a setting, investors care differently about an asset's comovement with falling markets as opposed to an asset's comovement with rising markets. This sounds like a description of the link between the typical carry trade - going long in high forward discount currencies and short in low forward discount currencies — and the return on the US stock market during the 2007/2008 mortgage crisis. Lustig and Verdelhan (2011) depict this relation in their Figure 4, here reproduced as Figure $1 .{ }^{3}$ The correlation between the carry trade return and the US stock market is about 0.7 during that mortgage crisis period in marked contrast to substantially lower degree of comovement in times of stock market upswings. Hence, it is natural to confront downside risk models with excess returns on foreign currencies.

\section{[about here Figure 1]}

We are not the first to employ a downside risk model variety to assess cross-sectional variation in currency returns. Dobrynskaja (2010) shows that the marginal contribution of downside risk on top of the exposure to the unconditional market return is priced in excess returns on portfolios of foreign currencies and stocks. She sorts the currency portfolios on past periods' interest rate differentials. More recently, Lettau et al. (2013) use a similar version of a downside risk model to understand returns on interest rate differential sorted portfolios of currencies as well as other asset classes such as commodities and bonds. Moreover, they examine more generally the relation of downside risk models to risk factors extracted from the principal component analysis. However, none of these papers distinguishes between global and country-specific components in the market return despite recent evidence on the success of global risk factors to explain average excess returns on currency portfolios (Lustig and Verdelhan, 2011; Lustig et al., 2011; Menkhoff et al., 2012a). ${ }^{4}$

\footnotetext{
${ }^{3}$ We thank Adrien Verdelhan for providing us with the original graphic file.

${ }^{4}$ Verdelhan (2012) shows that also country-specific risk can generate deviations from the UIP as emphasized in Backus et al. (2001).
} 
In addition, we contribute to the literature by examining bilateral foreign currency returns that are conditional on the previous month's forward discount. So far, downside risk models have been only applied to portfolios of foreign currencies. By considering bilateral currency excess returns conditional on the previous period's forward discount we are able to take transaction costs into account. Furthermore, we thus obtain a greater number of test assets and gain degrees of freedom in the cross-sectional regressions (Burnside, 2011) compared with studies focused on currency portfolios The focus on bilateral currency returns, however, limits the sample period compared with studies that focus on currency portfolios. This is a price to pay when one attempts to study exchange rates that are de facto at least close to a floating exchange rate regime. Reinhart and Rogoff (2004) point out that after the demise of Bretton Woods and well into the 1990s many de iure floating exchange rates were de facto pegs. For example, Dobrynskaja (2013) stresses that before the introduction of the euro in January 1999 nine other European currencies de facto tied their currency very closely to the Deutschmark. These insights are typically ignored in the currency return - risk factor literature by routinely including de facto pegged currencies in the formation of currency portfolios. It is not clear how the empirical analysis of currency portfolios is affected if, say, we have thirty US dollar currency returns to form portfolios but nine of these currencies are pegged to the Deutschmark, such that one third of the sample essentially mimics the Deutschmark's fluctuations against the US dollar. With these caveats in mind, we start our baseline sample with the introduction of the euro in January $1999^{5}$ and focus on bilateral, conditional currency excess returns relative to the US dollar.

Closely following Ang et al. (2006) in the setup of the downside risk model, we show that sensitivity to the global downside risk component of the US market return is marginally priced in the full sample of 19 developed and emerging markets' currencies over the period

\footnotetext{
${ }^{5}$ Our source of exchange rate data is Datastream which provides most US dollar forward and spot exchange rates only since January 1997 (see also Burnside at al., 2011). Greenway-McGrevy et al. (2012), for instance, also start their analysis of exchange rate predictability based on principal components of US dollar exchange rates in January 1999.
} 
from January 1999 to March 2013. The importance of the US-specific components of the market return in explanations of the conditional, bilateral currency returns under study is rather negligible. Differences in the exposure to global risk are associated with cross-sectional differences in bilateral currency returns.

Our subsample analysis further reveals that the global downside risk explanation of countrylevel excess returns on foreign currencies is largely driven by the emerging markets in the sample. The relation between excess returns on developed markets' currencies and global downside risk is, in contrary, less clear. We confirm the latter finding for developed markets in a sample from 1985 to 2013. Hence, if loss aversion is an inherent feature of the preferences of foreign currency investors, our results suggest that it is largely confined to the evaluation of investments into emerging markets' currencies. Lettau et al. (2013) provide contrasting evidence for portfolios of currencies in a longer sample (dating back to 1973) and covering more than 50 currencies in the portfolio formation. It is beyond the scope of this paper to assess if these differences in the empirical findings are related to the role of de iure floating versus de facto pegging currencies after the demise of the Bretton Woods system in this context.

Forming currency portfolios according to the sensitivities of exchange rate changes to the global downside risk results in a similar picture as our baseline evidence for bilateral currency excess returns. Importantly, we also show that controlling for global equity market volatility substantially weakens the explanatory power of the downside risk model for bilateral currency excess returns. In sum, our results suggest that downside risk models leave the critique of Burnside (2011) valid. It is hard to find a significant link between traditional risk factors, such as stock market returns, and currency excess returns.

The remainder of the paper is organized as follows. We present the definition of currency excess returns in section 2. We show our extension of the empirical version of the CAPM in 
Section 3 and describe the data in Section 4. Section 5 provides our econometric framework and the main results as well as a set of robustness checks. Finally, Section 6 concludes.

\section{Definition of currency excess returns}

We define currency excess returns as ex post deviations from the uncovered interest rate parity condition, i.e.

$$
\phi_{t+1}^{i}=i_{t}^{i}-i_{t}-\Delta s_{t+1}^{i}
$$

in which $\phi_{t+1}^{i}$ represents the currency excess return, $i_{t}^{i}$ is the country $i$ short-term interest rate, $i_{t}$ its home country, here US counterpart, and $\Delta s_{t+1}^{i}$ the change in the log spot exchange rate of country $i$ relative to the home currency. An increase in $s$ corresponds to an appreciation of the home or depreciation of the foreign currency.

We regard excess returns at the monthly frequency at which covered interest rate parity usually holds (Akram et al., 2008). Thus interest rate differentials are roughly equal to forward discounts

$$
i_{t}^{i}-i_{t} \approx f_{t}^{i}-s_{t}^{i}
$$

where $f_{t}^{i}$ is the $\log$ forward exchange rate and the $\log$ currency excess return can be written as a difference between the log forward discount and the log spot rate change

$$
\phi_{t+1}^{i}=\left(f_{t}^{i}-s_{t}^{i}\right)-\Delta s_{t+1}^{i}
$$

This representation is equivalent to buying a foreign currency in the forward market and selling it one period, here one month, later in the spot market:

$$
\phi_{t+1}^{i}=f_{t}^{i}-s_{t+1}^{i}
$$

In order to take transaction costs into account we examine conditional, bilateral foreign currency excess returns. The conditioning variable for the excess return in $t+1$ is the forward discount observed in $t$. If the forward discount in the previous month is positive, then we go long in the foreign currency $i$, i.e. 


$$
\phi_{t+1}^{i, l}=f_{t}^{i, b}-s_{t+1}^{i, a}
$$

If the forward discount in the previous month is negative, then we go short in the foreign currency next period, i.e.

$$
\phi_{t+1}^{i, s}=-f_{t}^{i, a}+s_{t+1}^{i, b}
$$

where $a$ and $b$ abbreviate "ask" and "bid" prices and $l$ and $s$ abbreviate "long" and "short" positions, respectively.

Since we focus on currency pairs, there is a lot of variation with respect to long and short positions in each bilateral exchange rate over our sample period. In addition, by using conditional currency excess returns we capture similar features of exchange rate data as portfolios of currencies that are sorted on forward discounts. The disadvantage of the use of bilateral currency returns is the loss of the sample period length. The advantage is related to the gains in the number of test assets and degrees of freedom in the cross-sectional regressions (Burnside, 2011).

\section{$3 \quad$ Methodology}

This section briefly motivates an empirical version of the Sharpe (1964) and Lintner (1965) CAPM as the starting point of our analysis. In a second step, we explain how we incorporate the distinction between country-specific and global risk into the empirical model. Finally, we introduce upside and downside risks into the empirical model.

\subsection{Why do we use an empirical model based on a CAPM?}

As highlighted in the introduction, standard models confronted with currency excess returns imply implausibly high estimates of the coefficient of relative risk aversion. For instance, the consumption-based models in Lustig and Verdelhan (2007) deliver a risk aversion coefficient of around 100. Galsband and Nitschka (2013) study excess returns on currency portfolios in an intertemporal version of the CAPM and also find implied risk aversion values of this 
magnitude. In this paper, we evaluate if we can circumvent this requirement. To impose discipline in this respect, we opt for an empirical version of the CAPM as a starting point.

As highlighted by Cochrane (2005) we can easily infer a CAPM from a consumption-based model under the assumption of logarithmic utility (Rubenstein, 1976). In the case of logarithmic utility, $u(C)=\ln (C)$, and under the assumption that the market or total wealth portfolio is a claim to future consumption flows, the price of the market portfolio, $P_{t}^{M}$, can be written as

$$
P_{t}^{M}=E_{t} \sum_{i=1}^{\infty} \delta^{i} \frac{u^{\prime}\left(C_{t+i}\right)}{u^{\prime}\left(C_{t}\right)} C_{t+i}=\frac{\delta}{1-\delta} C_{t},
$$

where $E_{t}$ is the expectation operator and $\delta$ denotes the individual time preference parameter.

The return on the market portfolio, $R_{t}^{M}$, is then proportional to consumption growth:

$$
R_{t}^{M}=\frac{P_{t+1}^{M}+C_{t+1}}{P_{t}^{M}}=\frac{(\delta /(1-\delta)+1)}{\delta /(1-\delta)} \frac{C_{t+1}}{C_{t}}=\frac{1}{\delta} \frac{C_{t+1}}{C_{t}} .
$$

Clearly, other motivations of a CAPM are possible but the logarithmic utility case illustrates the restriction of the coefficient of relative risk aversion. To see this, remember that a power utility function ${ }^{6}, u(C)=\frac{C^{1-\gamma}-1}{1-\gamma}$, in which $\gamma$ reflects the coefficient of relative risk aversion, converges to logarithmic utility when the risk aversion coefficient approaches unity. We choose this representation with low imposed levels of risk aversion as a starting point to study the cross-sectional dispersion in bilateral, conditional currency excess returns.

\subsection{Incorporating country-specific and global risk in the market return}

A simple distinction between country-specific and global risk factors in the framework of the standard CAPM allows to easily account for the previous literature on the importance of global risks for foreign exchange markets (Lustig et al., 2011; Lustig and Verdelhan, 2011; Menkhoff et al., 2012a).

\footnotetext{
${ }^{6}$ For simplicity, here we show the case when we add a constant to the "typical" power utility function .
} 
From a US investor's perspective, a standard CAPM setting implies that differences in the sensitivities to the US market return should explain average currency excess returns. Sensitivities of the bilateral currency excess return vis-à-vis country $i$ obey

$$
\beta^{i, M}=\frac{\operatorname{cov}\left(\phi_{t}^{i}, r_{t}^{M, U S}\right)}{\operatorname{var}\left(r_{t}^{M, U S}\right)} .
$$

where $r_{t}^{M, U S}$ is the return on the US stock market in excess of the risk-free rate.

We introduce the distinction between country-specific and global components of the US market excess return by regressing the US market return on a world market return. The fitted value of this regression, i.e. that part of the US market return that comoves perfectly with the world market return, is henceforth referred to as "global" market return component. We refer to the residual of this regression as the "US-specific" component which is orthogonal to the global component by construction.

In the empirical analysis, we explicitly distinguish between sensitivities to country-specific and global components in the US market return. The exposure to the country-specific component is measured as

$$
\beta^{i, \text { specific }}=\frac{\operatorname{cov}\left(\phi_{t}^{i}, r_{t}^{M, \text { specific }}\right)}{\operatorname{var}\left(r_{t}^{M, \text { specific }}\right)}
$$

while the exposure to the global component is defined as

$$
\beta^{i, \text { global }}=\frac{\operatorname{cov}\left(\phi_{t}^{i}, r_{t}^{M, \text { global }}\right)}{\operatorname{var}\left(r_{t}^{M, \text { global }}\right)} .
$$

\subsection{Upside and downside risks}

Lustig and Verdelhan (2011) show that the payoff from a typical carry trade strategy and the excess return on the US stock market are highly correlated in the recent crisis period but virtually uncorrelated in more tranquil times. In addition, Christiansen et al. (2011) and Cenedese (2012) show that the sensitivity to the market return is regime-dependent. These findings could be a reflection of a more general notion of loss aversion. Investors in foreign 
exchange markets place a greater emphasis on the disutility of large losses than on utility improvements from equally high gains (Kahnemann and Tversky, 1979).

The general concept of loss aversion plays an important role in the early portfolio theory literature (Markowitz, 1959) and asset pricing theory (Bawa and Lindenberg, 1977; Harlow and Rao, 1989; Hogan and Warren, 1974; Jahankhani, 1976). However, Ang et al. (2006) were the first to show that downside risk is actually priced in average stock returns. Stock returns which covary strongly with the falling stock market return should offer relatively high average returns to compensate for downside risk exposure. Downside risk, however, appears to be only one determinant of stock returns. Size or the ratio of book-to-market equity still have an impact on expected stock returns at the firm-level after controlling for downside risk exposure.

Based on the evidence that returns on carry trade strategies are highly correlated with the market return in times of distress (Lustig and Verdelhan, 2011), we apply this reasoning to bilateral currency excess returns. Dobrynskaja (2010) and Lettau et al. (2013) analyse currency portfolios formed according to interest rate differentials in a similar framework. One important difference to these studies is our distinction between US-specific and global components in the market return. Since differences in the exposure to global risks can rationalize differences in average returns on currency portfolios (Lustig et al., 2011; Menkhoff et al., 2012a), we assess if a similar observation can be made for bilateral excess returns.

The baseline definition of upside and downside states is based on the US market return. If the market return is negative, we are then in a downside state. If the market return is bigger than or equal to zero, we are then in an upside state. Dobrinskaja (2010) makes the same assumption in her assessment of currency portfolio and stock portfolio returns while Lettau et al. (2013) argue that the threshold should be defined as multiple of the market return standard deviation around its mean. They chose one standard deviation below the mean as a 
benchmark. We first evaluate the definition of upside and downside risk states according to positive or negative thresholds for the market return and then consider the Lettau et al. (2013) definition of the downside risk state.

Taken together, our baseline empirical model can distinguish between four variants of currency excess returns' sensitivity to the market return: Upside risk as well as downside risk in the US-specific and the global component of the market return.

More formally, these sensitivities are

$$
\begin{aligned}
& \beta_{\text {up }}^{i, \text { specific }}=\frac{\operatorname{cov}\left(\phi_{t}^{i}, r_{t}^{M, \text { specific }} \mid r_{t}^{M, U S} \geq 0\right)}{\operatorname{var}\left(r_{t}^{M, \text { specific }} \mid r_{t}^{M, U S} \geq 0\right)} \\
& \beta_{\text {down }}^{i, \text { specific }}=\frac{\operatorname{cov}\left(\phi_{t}^{i}, r_{t}^{M, \text { specific }} \mid r_{t}^{M, U S}<0\right)}{\operatorname{var}\left(r_{t}^{M, \text { specific }} \mid r_{t}^{M, U S}<0\right)}
\end{aligned}
$$

and

$$
\begin{aligned}
& \beta_{\text {up }}^{i, \text { global }}=\frac{\operatorname{cov}\left(\phi_{t}^{i}, r_{t}^{M, \text { global }} \mid r_{t}^{M, U S} \geq 0\right)}{\operatorname{var}\left(r_{t}^{M, \text { global }} \mid r_{t}^{M, U S} \geq 0\right)} . \\
& \beta_{\text {down }}^{i, \text { global }}=\frac{\operatorname{cov}\left(\phi_{t}^{i}, r_{t}^{M, \text { global }} \mid r_{t}^{M, U S}<0\right)}{\operatorname{var}\left(r_{t}^{M, \text { global }} \mid r_{t}^{M, U S}<0\right)} .
\end{aligned}
$$

\section{Data}

In our benchmark specification, we examine a sample of monthly US dollar exchange rates from 19 economies for which spot and forward exchange rates are available during the entire sample period from January 1999 to March 2013. According to the Morgan Stanley Capital International (MSCI) classification of stock markets our sample comprises 10 developed and 9 emerging markets. Table 1 gives an overview and presents the mean conditional excess return on each currency pair along with its standard error. All of the moments are in percent p.a.

There is a large dispersion in the mean, conditional excess returns across currency pairs. For example, from a US investor's perspective, the conditional excess return, i.e. going long and 
short according to the previous period's forward discount, on an investment in the Australian dollar delivers a return of more than 7\% p.a. By contrast, the conditional excess return on a Swiss franc investment lies around $-4 \%$ p.a. The standard errors of the conditional, currency excess returns are rather large. Only the return on the Australian dollar is significantly different from zero at conventional significance levels. Due to their substantial noisiness, bilateral currency excess returns are a challenge for asset pricing and macroeconomic models alike. However, there are significant cross-sectional differences between these bilateral currency excess returns. These differences are the focus of our study. Dobrynskaja (2010) and Lettau et al. (2013) analyse interest rate differential or forward discount sorted currency portfolio returns and find the distinction between upside and downside states of the market return useful in understanding their average excess returns. We examine whether this finding holds for excess returns on currency pairs.

With respect to the choice of currencies, we only use currencies for which forward and spot rate data is available over the entire sample period. Moreover, countries which essentially peg or officially tie their currencies to other single currencies are not included. For instance, we do not consider the Danish krone as it is closely tied to the euro. The krone is only allowed to fluctuate within a narrow band around the euro (+/- 2.5\%) even though the European Exchange Rate Mechanism II (ERM II) would allow fluctuations of +/- 15\%. By contrast, we include Singapore in our sample as it manages its currency against an undisclosed basket of other currencies. Please note that Eastern European countries such as Czech Republic, Poland or Hungary are not yet members of ERM II.

As a robustness check, we consider the time period from January 1985 to March 2013 for our subsample of developed market currencies. The data sources for the spot and foreign 
exchange rates (bid and ask) are WM/Reuters and Barclays available via Datastream. ${ }^{7}$ End of month values are constructed from daily rates.

\section{[about here Table 1]}

To disentangle US specific from global market components in the US stock market return, we use the MSCI standard price index for the US and the MSCI World price index. Both indices are denominated in US dollars and measured at the end of the month. These data are freely available on http://www.msci.com/. MSCI indices have the advantage that they are broad and calculated using the same methodology.

We use daily data on the MSCI country stock indices (price indices denominated in local currency) to calculate a measure of global equity market volatility. We follow Lustig et al. (2011) and calculate this measure in two steps. First, we compute the standard deviation of daily returns in a month for each of the country indexes. Then we take the cross-sectional mean of these monthly volatility series to obtain the measure of global equity market volatility. We use these volatility series as control variables in our robustness checks since falling stock markets are typically associated with rising volatility. So, a priori, it is not clear if exposure to the market return in downside states is different than exposure to global financial market volatility.

Finally, we use the 1-month T-bill rate from the Fama and French Research Factors file as the risk-free rate to calculate excess returns on the stock market indices from the U.S. investor's perspective. This data is published on Kenneth French's website. ${ }^{8}$

\section{$5 \quad$ Econometric framework, baseline results and robustness checks}

In this section, we present our basic econometric framework, the baseline results and a variety of robustness checks.

\footnotetext{
${ }^{7}$ Most US dollar exchange rates on Datastream are only available since January 1997 and not for all of the currencies under study.

${ }^{8}$ http://mba.tuck.dartmouth.edu/pages/faculty/ken.french/
} 


\subsection{Econometric framework and baseline results}

Our assessment of the ability of CAPM-based models to explain the cross-sectional dispersion in bilateral currency excess returns exploits the standard beta representation of the basic asset pricing equation. We estimate the beta representation via the Fama-MacBeth methodology (Fama-MacBeth, 1973) in a series of cross-sectional regressions of the excess returns on their sensitivities to the underlying risk factors at each point in time.

To form a basis for comparison, we study four model variants with the 19 individual excess returns under study. The first variant is the standard CAPM which implies that sensitivity to the US market return is the only determinant of average currency excess returns. The results of the cross-sectional regression of the following form

$$
\phi_{t}^{i}=\lambda_{t}^{M} \hat{\beta}^{i, M}+v_{t}^{i}, \forall t
$$

are summarized in Panel A of Table 2. The table provides a cross-sectional $R^{2}$, the average risk price estimates, $\lambda$, the mean squared pricing errors (mspe) and the mean absolute pricing errors (mape) in percentage points per annum.

Panel A of Table 2 shows that the standard CAPM from the US perspective summarized in Equation (16), seems to capture some of the dispersion in the 19 monthly currency excess returns under study. The risk price estimate is positive and significant. However, the standard CAPM explains only $15 \%$ of the cross-sectional variation in currency excess returns at the country level during the period between January 1999 and March 2013. In addition, the pricing errors are quite large and the risk price estimate above $40 \%$ p.a. is far bigger than the sample mean of the US market excess return of $0.27 \%$ p.a. over the sample period or the longrun mean US market excess return of about 5\% p.a. The mean return is approximately the theoretically correct price of market risk since a regression of the market return on itself delivers a sensitivity of unity. Against this background, the standard CAPM does not seem to be particularly helpful in understanding average currency excess returns in line with the points made by Burnside (2011) and Burnside et al. (2011). 
Next we question whether a distinction between country-specific and global components in the market return does a better job in this respect. Panel B of Table 2 displays the estimates of Fama-MacBeth cross-sectional regressions of currency excess returns on their exposure to the US-specific and the global component of the market return

$$
\phi_{t}^{i}=\lambda_{t}^{\text {specific }} \hat{\beta}^{i, \text { specific }}+\lambda_{t}^{\text {global }} \hat{\beta}^{i, g l o b a l}+v_{t}^{i}, \forall t
$$

In line with several studies (Lustig and Verdelhan, 2011; Lustig et al., 2011; Menkhoff et al., 2012a), global risk is relatively more important than country-specific risk in explaining the patterns in the data. In contrast to the country-specific component, sensitivity to the global component of the US market return seems to be priced in bilateral currency excess returns. This CAPM variant produces lower pricing errors than the standard CAPM and the crosssectional fit is raised to more than $40 \%$. However, the risk price of sensitivity to the global market return component is still far too high. The distinction between country-specific and global components of the market return is hence not sufficient to explain average currency excess returns.

Lustig and Verdelhan (2011) highlight a strong relation between currency excess returns and the market return in times of distress. Christiansen et al. (2011) and Cenedese (2012) document regime-dependency in the relation between the market return and currency excess returns. Against this backdrop, Dobrynskaja (2010) proposes a downside risk version of the CAPM to analyse cross-sectional differences in excess returns on currency and stock portfolios. More recently, Lettau et al. (2013) use a downside risk model to show that downside risk is priced in returns on portfolios of various asset classes. Based on these studies, we assess the following specification

$$
\phi_{t}^{i}=\lambda_{\text {up }, t}^{\text {specific }} \hat{\beta}_{u p}^{i, \text { specific }}+\lambda_{\text {down }, t}^{\text {specific }} \hat{\beta}_{\text {down }}^{i, s p e c i f i c}+\lambda_{u p, t}^{\text {global }} \hat{\beta}_{u p}^{i, g l o b a l}+\lambda_{\text {down }, t}^{\text {global }} \hat{\beta}_{\text {down }}^{i, g l o b a l}+v_{t}^{i}, \forall t
$$

where the upside and downside sensitivities follow the definitions in Equations (12) to (15) in Panel C of table 2. 
Our results confirm that the distinction between upside and downside risks matters. It is the global downside market risk that is marginally, significantly priced in average currency excess returns. The pricing errors drop compared with the estimates in panels A and B of Table 2. Furthermore, this empirical model explains roughly $60 \%$ of the cross-sectional dispersion in the bilateral currency excess returns with lower risk price estimates as compared with the case of the unconditional CAPM specifications. Lettau et al. (2013) define downside states as states of the world in which the market return is one standard deviation below its sample mean. If it is above this value, then this state of the world is considered as an upside risk state. We follow this definition and report these results in panel D of table 2. The risk price estimates vary a bit. Upside risk as defined above included also negative market return values but the general conclusion prevails. Global downside risk is reflected in conditional, bilateral currency excess returns. Most of the evidence for a global downside risk compensation comes from states of the world in which the market return took relatively large negative values. In our baseline sample period, there are 26 dates which qualify as downside risk states according to the Lettau et al. (2013) definition.

\section{[about here: Table 2]}

A general criticism of the attempts to link excess returns on currencies to traditional risk factors such as the market return or consumption growth is the observation that the individual sensitivities from time series regressions in the Fama-MacBeth regressions are not statistically different from zero (Burnside, 2011). This criticism applies to the downside risk models as well. Table 3 provides an overview of the estimated sensitivities to the four market return components from panel D of table 2 along with their Newey-West (1987) corrected standard errors applying a lag length of four months in the correction. Individually, most of the sensitivities to the market return components are indistinguishable from zero.

[about here Table 3] 
However, Lustig and Verdelhan (2011) argue that the economically important question is if the sensitivities differ from each other and whether these differences are reflected in crosssectional dispersion in currency excess returns. In terms of our estimates of global downside risk sensitivities, let us consider the Australian dollar return (about 7\% p.a. mean return) and the British pound excess return (about $-1.2 \%$ p.a. mean return). Table 3 estimates the exposure of the excess return on the Australian dollar to be 0.38 with a standard error of about 0.26, while the corresponding beta of the British pound is equal to -0.29 with a standard error of 0.19 . The respective ranges of the point estimates are 0.12 to 0.64 and -0.10 to -0.48 . Hence, despite imprecise measurement of the point estimates, there are cross-sectional, significant differences in the sensitivities in the global downside risk betas that seem to be related in the differences between mean bilateral currency excess returns. We challenge this view in the subsequent section.

\section{$5.2 \quad$ Robustness Checks}

This section provides several robustness checks of the baseline results presented in panel D of table 2 to provide a comparison with Lettau et al. (2013) in terms of the definition of downside risk states. First, we show that the downside risk sensitivities indeed differ from simple unconditional exposure to the market return. Yet, our findings suggest that we cannot clearly distinguish the downside risk from financial market volatility. Second, splitting the sample into developed and emerging markets reveals striking differences between the two country groups. While the global downside risk is priced in the conditional currency excess returns of emerging markets, the global upside risk is reflected in the conditional currency excess returns of developed markets. The analysis of a longer sample period starting in January 1985 for ten developed markets further suggests a minor role of global downside risk in determining excess returns on foreign currencies of developed markets. Third, portfolio formation based on the average sensitivity of exchange rate changes to the global downside component of the market return confirms the evidence from bilateral currency excess returns. 
Finally, we gauge the impact of the recent global financial crisis on our baseline results and work with a shorter sample period up until June 2007. We find that the exclusion of emerging markets from the sample has a greater impact on the relevance of the downside risk explanation of currency excess returns than excluding the recent crisis period.

5.2.1 Downside risk, unconditional market return exposure and global equity market volatility

As emphasized by Ang et al. (2006), it is important to control the sensitivities to the market return in the upside and downside states for the unconditional market return exposure as upside and downside states could simply coincide with periods of low and high unconditional sensitivities to the market return. Therefore, we augment our baseline specification summarized in equation (18) to account for the marginal contribution of downside risk on top of the unconditional market return exposure:

$\phi_{t}^{i}=\lambda_{\text {up }, t}^{\text {specific }}\left(\hat{\beta}_{\text {up }}^{i, \text { specific }}-\beta^{i, M}\right)+\lambda_{\text {down }, t}^{\text {specific }}\left(\hat{\beta}_{\text {down }}^{i, \text { specific }}-\beta^{i, M}\right)+\lambda_{\text {up }, t}^{\text {global }}\left(\hat{\beta}_{u p}^{i, \text { global }}-\beta^{i, M}\right)$ $+\lambda_{\text {down }, t}^{\text {global }}\left(\hat{\beta}_{\text {down }}^{i, \text { global }}-\beta^{i, M}\right)+v_{t}^{i}, \forall t$,

Panel A of table 4 presents the corresponding risk price estimates as well as cross-sectional measures of fit. In sum, despite slightly lower measures of fit, our baseline results are unchanged both in economic and statistical terms.

A related, natural concern is that our risk measures could be a reflection of the exposure of foreign currencies to global equity market volatility. Volatility tends to be high when the market return is falling and vice versa. Moreover, Ranaldo and Söderlind (2010) find a relation between currency returns and stock market volatility levels in their assessment of safe haven currencies. Safe haven currencies appreciate when global financial market volatility is high. In addition, Lustig et al. (2011) show that their carry trade factor, the decisive risk factor to explain the cross-section of average excess returns on currency portfolios, is positively correlated with changes in global equity market volatility. 
We follow Lustig et al. (2011) in calculating global equity market volatility from daily returns on the MSCI stock indices of the countries under study. We regress our bilateral, conditional currency excess returns on the level as well as on log changes in the global equity volatility series to obtain the currency excess returns' sensitivities to equity market volatility in the upside and downside market states as controls in our downside risk model. The estimate equations obey

$\phi_{t}^{i}=\lambda_{u p, t}^{\text {specific }}\left(\hat{\beta}_{u p}^{i, \text { specific }}-\beta_{u p}^{i, \text { VOL }}\right)+\lambda_{\text {down }, t}^{\text {specif }}\left(\hat{\beta}_{\text {down }}^{i, \text { specific }}-\beta_{\text {down }}^{i, \text { VOL }}\right)+\lambda_{\text {up }, t}^{\text {global }}\left(\hat{\beta}_{u p}^{i, \text { global }}-\beta_{u p}^{i, \text { VOL }}\right)$

$+\lambda_{\text {down }, t}^{\text {global }}\left(\hat{\beta}_{\text {down }}^{i, \text { global }}-\beta_{\text {down }}^{i, \text { OOL }}\right)+v_{t}^{i}, \forall t$,

for the level of global equity market volatility, VOL, and

$\phi_{t}^{i}=\lambda_{u p, t}^{\text {specific }}\left(\hat{\beta}_{u p}^{i, \text { specific }}-\beta_{u p}^{i, \Delta V O L}\right)+\lambda_{\text {down }, t}^{\text {specific }}\left(\hat{\beta}_{\text {down }}^{i, \text { specific }}-\beta_{\text {down }}^{i, \Delta V O L}\right)+\lambda_{u p, t}^{\text {global }}\left(\hat{\beta}_{u p}^{i, g l o b a l}-\beta_{u p}^{i, \Delta V O L}\right)$

$+\lambda_{\text {down }, t}^{\text {global }}\left(\hat{\beta}_{\text {down }}^{i, \text { global }}-\beta_{\text {down }}^{i, \Delta V O L}\right)+v_{t}^{i}, \forall t$,

for the log changes in the global equity market volatility, $\Delta \mathrm{VOL}$. The respective estimates are presented in panel B and panel C of table 4.

The results in panel B of table 4 qualify the notion of a global downside risk premium in conditional bilateral currency excess returns. After controlling for the global equity market volatility, we find no strong support for a tight link between global downside risk and average currency excess returns. In fact, these results rather suggest that global upside and downside risk cannot be clearly distinguished from global equity market volatility. This observation hence questions what exactly is the underlying economic rationale of empirical downside risk models which are motivated with investors' loss aversion. Uncertainty aversion or aversion to load on potential crash risk through foreign currency investments could also be reflected in downside risk exposures as the results in panel B of table 4 suggest. Interestingly, panel C of table 4 highlights that once we control for changes in equity market volatility our baseline results remain unaffected.

[about here Table 4] 


\subsubsection{Country subsamples and downside risk beta sorted currency portfolios}

Our sample of currencies consists of 10 developed and 9 emerging economies according to the MSCI classification of stock markets. In this section we investigate how our results pertain to each class of countries separately. This exercise is based on the baseline pricing relation presented in equation (18). The results are presented in table 5.

Panel A of table 5 presents the results for the subsample of nine currency returns from emerging markets over the baseline sample period from January 1999 to March 2013. For this country subsample, the estimated risk prices are statistically indistinguishable from zero despite better measures of cross-sectional fit. Panel B of table 5 adds insult to injury by suggesting that it is global upside risk that is priced in the cross-section of developed markets' currencies. The risk price of global upside risk is statistically significant as opposed to the risk price of global downside risk. This latter finding is corroborated by the results provided in panel C of table 5. Tests of developed markets' currency excess returns over an extended sample period from January 1985 to March 2013 reject the global downside risk story too. In sum, the results presented in table 5 suggest that a downside risk explanation of crosssectional differences in bilateral, conditional currency excess returns is largely confined to emerging markets' currencies if at all.

An alternative would be to additionally allow for time-variation in the sensitivities to upside and downside risk components of the market return. For instance, Lustig et al. (2011) stress that it is important to allow for time variation in the sensitivity to their carry trade factor in order to rationalize the cross-section of bilateral currency excess returns in their model. However, following the Lettau et al. (2013) definition of downside states of the world, in our baseline sample period 26 dates qualify as downside risk states only and there are 44 respective dates in the long sample period from 1985 to 2013. In view of the low number of observations, it appears infeasible to allow for additional time variation in the market return exposures conditional on upside and downside risk states. 
One might also object that the bilateral currency excess returns are simply too noisy. Instead, portfolios sorted on downside risk beta might provide a better hint at the explanatory power of downside risk for currency excess returns. In addition, it should be the covariation of exchange rate changes, $-\Delta s_{t}^{i}$, with risk factors following from the definition of currency excess returns in equation (3), that determines the risk premium on foreign currency investments. Currency portfolios based on sensitivities of exchange rate changes to risk factors might shed light on this issue too. We thus regress $-\Delta s_{t}^{i}$ for each currency $i$ on the contemporaneously measured four different market return components to obtain the exchange rates' analogues of the sensitivities in equations (12) to (15). For ease of comparison, we hold the sample period constant from January 1999 to March 2013. Table 6 reports these sensitivities along with the corresponding Newey-West corrected standard errors.

\section{[about here Table 6]}

Based on these betas we form two portfolios. One portfolio consists of the five currencies with the highest downside risk beta and another portfolio consisting of the five currencies with the lowest downside risk beta. To take into account transaction costs we take a long position in the high global downside risk portfolio and a short position in the low global downside risk currency portfolio. The excess returns in the portfolios are equally weighted averages of the country-level excess returns as is common in the literature on currency portfolios sorted on interest rate differentials. In addition, we deliberately focus on the two extreme portfolios. The most significant spread in currency portfolio returns is between the extreme portfolios (Lustig and Verdelhan, 2007; Lustig et al., 2011).

Panel A of table 7 presents the mean excess returns on the two portfolios separately, their return difference and the associated standard errors of these portfolio returns in parentheses below the mean returns. All moments are expressed in \% p.a. The high downside risk portfolio consists of returns relative to the currencies of Australia, Hungary, Mexico, Norway and Poland. The low downside risk portfolio consists of returns on currencies of India, Japan, 
Kuwait, Singapore and Switzerland. A long position in the high global downside risk portfolio delivers an annualized excess return of about $3.6 \%$ p.a. while shorting the low global downside risk beta currencies gives a return of $-2.7 \%$ p.a. such that the return on the strategy to go long in high and short in low global downside risk currencies delivers a return of $6.2 \%$ p.a. The standard errors indicate that the mean returns are statistically different from zero. This sorting exercise confirms our baseline results for currency pairs which suggest that global downside risk is priced in currency excess returns. Panel B of table 7 gives the same statistics when we focus on the ten currencies from developed markets. In this case we use three currencies to form the high and low global downside risk portfolios. ${ }^{9}$ Evidently, the low global downside risk portfolio return is not distinguishable from zero. The return difference between high and low global downside risk currency portfolios is only marginally different from zero. The picture is fundamentally different when we focus on the emerging markets sample. ${ }^{10}$ Panel $\mathrm{C}$ of table 7 shows that the return difference between the portfolios of high and low global downside risk sorted currency portfolios is larger and more significant. Supporting our baseline conclusions, the portfolio formation exercise confirms that a global downside risk explanation of currency excess returns is to most extent driven by the emerging markets in our sample.

\section{[about here Table 7]}

\subsubsection{What is the impact of the global financial crisis since 2007?}

In his critique on studies that document an economically important as well as statistically significant relation between standard risk factors and currency excess returns, Burnside (2011) stresses that the link is indeed strong in the recent crisis period but very much confined to that period. Related to this point, Grisse and Nitschka (2013) follow Verdelhan (2012) and assess safe haven characteristics of Swiss franc exchange rates vis-à-vis mostly developed

\footnotetext{
${ }^{9}$ The high global downside risk portfolio then contains the returns on currencies of Australia, New Zealand and Norway. The low global downside risk portfolio comprises currencies of Japan, Singapore and Switzerland.

${ }^{10}$ In this case, the high global downside risk currency portfolio comprises currencies of Hungary, Poland and Mexico. The low global downside risk portfolio covers currencies of India, Kuwait and Thailand.
} 
countries in UIP regressions augmented with risk factors. They find that cross-sectional differences in the sensitivity of these Swiss franc exchange rates to global risk are mainly due to the period from 2007 to 2009 .

The underlying economic concept of downside risk models is loss aversion which could be particularly pronounced during crisis periods but should be more general than that. Therefore, we assess the explanatory power of our baseline downside risk model specification but restrict the sample period to January 1999 to June 2007. Thus the sample ends before first tensions on money markets which mark the onset of the global financial crisis (Brunnermeier et al., 2009). We report the cross-sectional pricing results for our sample of 19 bilateral, conditional currency excess returns during this restricted pre-crisis period. In addition, we repeat the portfolio formation exercise from section 5.2.2 and report excess returns on portfolios sorted on the exposure of the unconditional exchange rate changes to global downside risk for period from January 1999 to June 2007. Limiting the sample period reduces the number of downside states of the world to 12 compared with 26 over our baseline sample. Recall that we use the definition of downside states employed by Lettau et al. (2013), i.e. when the market return is one standard deviation below its sample average.

We present the sensitivities of the bilateral, conditional currency excess returns to the four market return components in table 8 . The estimates of sensitivities to the market return components vary quite a bit compared with the baseline estimates presented in table 3 . Interestingly, however, the estimates of global downside risk sensitivities are in general slightly more precisely estimated. We observe more betas that are clearly or at least marginally different from zero. Hence, by restricting the sample period we do not necessarily lose precision in the estimation of the global downside risk sensitivities.

\section{[about here Table 8]}

What does this imply for the cross-sectional pricing of the bilateral, conditional currency excess returns under study? Panel A of table 9 gives a first answer. It presents risk price 
estimates and the measures of cross-sectional fit. It is apparent that the cross-sectional fit deteriorates significantly once we exclude the crisis period since mid-2007. The pricing errors increase drastically and the $R^{2}$ statistic drops from $60 \%$ in the baseline results to $25 \%$. In addition, based on the risk price estimates and the uncertainty surrounding these estimates we cannot tell if it is the downside rather than upside risk which is a potentially priced source of risk in the bilateral currency excess returns.

Yet, the sensitivities of the bilateral, conditional currency excess returns are still imprecisely measured. Sorting portfolios based on the exposure of unconditional exchange rate changes to the global downside risk component of the market return might provide a sharper picture. Panel B of table 9 presents mean excess returns and standard errors of currency portfolios that are sorted according to the exposure of unconditional, log exchange rate changes over the sample period from January 1999 to June 2007 to the global downside risk component of the US market return. These sensitivities are additionally presented in table 10 . We report excess returns on long positions in the high beta portfolios and short positions in the low beta portfolios. Again, in the full sample of countries the high and low beta portfolios each comprise five currencies.

The strategy of taking a long position in the portfolio of the high downside risk currencies and simultaneously shorting the low downside risk currencies produces a significant return of roughly $9 \%$ p.a. This result is very much in line with the portfolio formation for the baseline sample period presented in table 7 . We obtain similar evidence from the country subsamples as in the baseline sample period, i.e. almost no relation between sensitivities to global downside risk and developed markets' currency excess returns but a strong link in the emerging markets subsample. The portfolio formation exercise hence suggests that it is not so much the recent crisis period that drives the evidence in favour of a downside risk explanation of currency excess returns but the presence of emerging markets in our sample. 


\section{[about here Table 10]}

\section{Conclusions}

The correlation between standard risk factors, such as the return on the market portfolio, and the excess returns on foreign currencies is strong in times of crisis. Based on this observation, models that explicitly distinguish between states of the world in which the market return is falling or rising are successful in explaining excess returns on currency portfolios and portfolios of other asset classes (Dobrynskaja, 2010; Lettau at al., 2013). The economic rationale behind these models is the notion of loss-aversion, i.e. investors tend to value the disutility of a certain loss of wealth more than the utility of an equally high gain. At first glance, our empirical results for bilateral, conditional currency excess returns seem to corroborate the results obtained for currency portfolios. We extend this literature by providing evidence on the importance of the global component in downside risk for cross-sectional explanations of average excess returns on currency pairs. However, our empirical analysis reveals at least two additional points which lead to a more sceptical appraisal of downside risk models for currency returns.

First, we show that controlling for volatility on global equity markets leads to a significant deterioration of the explanatory power of downside risk models for bilateral currency excess returns. This finding raises doubts on the role of loss aversion as opposed to uncertainty aversion or reluctance to load on crash risk as the underlying economic concept of the empirical downside risk model that we use in our asset pricing exercises. Second, the evidence in favour of a downside risk explanation for excess returns on currency pairs stems from the currencies of emerging markets in our sample. The link between downside risk and average excess returns on developed markets' currencies is substantially weaker. This finding would suggest that different preferences are at work when evaluating the risk-return trade-off in foreign currency investments in emerging versus developed markets. Taken together, our 
paper provides further support for Burnside (2011) cautioning against the weak link between currency excess returns and standard risk factors. 


\section{References}

Ang, Andrew and Joseph Chen (2010), "Yield Curve Predictors of Foreign Exchange Returns", Working Paper.

Ang, Andrew, Joseph Chen and Yuhang Xing (2006), "Downside Risk", Review of Financial Studies 19, 1191-1239.

Akram, Q. Farook, Dagfinn Rime and Lucio Sarno (2008), "Arbitrage in the Foreign Exchange Market: Turning on the Microscope", Journal of International Economics 76, 237253.

Backus, David K., Silverio Foresi and Christopher I. Telmer (2001), "Affine Term Structure Models and the Forward Premium Anomaly", Journal of Finance 56, 279-304.

Backus, David K., Federico Gavazzoni, Christopher I. Telmer and Stanley E. Zin (2010), "Monetary Policy and the Uncovered Interest Parity Puzzle", NBER Working Paper 16218.

Bansal, Ravi and Magnus Dahlquist (2000), “The Forward Premium Puzzle: Different Tales from Developed and Emerging Markets", Journal of International Economics 51, 115-144.

Bawa, Vijaj S. and Eric B. Lindenberg (1977), "Capital Market Equilibrium in a Mean-Lower Partial Moment Framework”, Journal of Financial Economics 5, 189-200.

Botshekan, Mahmoud, Roman Kraeussl and Andre Lucas (2012), "Cash Flow and Discount Rate Risk in Up and Down Markets: What is Actually Priced?", forthcoming Journal of Financial and Quantitative Analysis.

Brunnermeier, Markus K., Stefan Nagel and Lasse H. Pedersen (2009), "Carry Trades and Currency Crashes”, NBER Macroeconomic Annual 2008, Vol. 23, 313-347.

Burnside, Craig (2011), "The Cross Section of Foreign Currency Risk Premia and Consumption Growth Risk: Comment”, American Economic Review 101, 3456-3476.

Burnside, Craig, Martin Eichenbaum, Isaac Kleshchelski and Sergio Rebelo (2011), "Do Peso Problems Explain the Returns to the Carry Trade?", Review of Financial Studies 24, 853-891.

Cenedese, Gino (2012), “Safe Haven Currencies: A Portfolio Perspective”, Working Paper.

Christiansen, Charlotte, Angelo Ranaldo and Paul Söderlind (2011), "The Time-Varying Systematic Risk of Carry Trade Strategies", Journal of Financial and Quantitative Analysis $46,1107-1125$.

Cochrane, John H. (2005), “Asset Pricing”, revised edition, Princeton University Press, Princeton.

Dobrynskaja, Victoria (2010), "Downside Risk of Carry Trades", CAS Working Paper $13 / 2010 / 01$.

Dobrynskaja, Victoria (2013), “Currency Downside Risk and Macroeconomic Variables", Working Paper. 
Fama, Eugene F. (1984), "Forward and Spot Exchange Rates", Journal of Monetary Economics 14, 319-338.

Fama, Eugene F. and James D. MacBeth (1973), "Risk, Return and Equilibrium: Empirical Tests", Journal of Political Economy 81, 607-636.

Farhi, Emanuel, Samuel Fraiberger, Xavier Garbaix, Romain Ranciere and Adrien Verdelhan (2013), "Crash Risk in Currency Markets”, Working Paper.

Farhi, Emanuel and Xavier Garbaix (2011), "Rare Disasters and Exchange Rates", Working Paper.

Galsband, Victoria (2012), "Downside Risk of International Stock Returns", Journal of Banking and Finance 36, 2379-2388.

Galsband, Victoria and Thomas Nitschka (2013), "Foreign Currency Returns and Systematic Risks", forthcoming Journal of Financial and Quantitative Analysis.

Greenaway-McGrevy, Ryan, Nelson C. Mark, Donggyu Sul and Jyh-Lin Wu (2012), "Exchange Rates as Exchange Rate Common Factors", Working Paper.

Grisse, Christian and Thomas Nitschka (2013), "On Financial Risk and the Safe Haven Characteristics of Swiss Franc Exchange Rates", SNB Working Paper 2013-04.

Gul, Faruk (1991), “A Theory of Disappointment Aversion”, Econometrica 59, 667-686.

Hansen, Lars P. and Robert J. Hodrick (1980), "Forward Exchange Rates as Optimal Predictors of Future Spot Rates: An Econometric Analysis", Journal of Political Economy 88, 829-853.

Harlow, W.V. and Ramesh K.S. Rao (1989), "Asset Pricing in a Generalized Mean-Lower Partial Moment Framework: Theory and Evidence", Journal of Financial and Quantitative Analysis 24, 285-311.

Hogan, William W. and James M. Warren (1974), "Toward the Development of an Equilibrium Capital-Market Model Based on Semivariance", Journal of Financial and Quantitative Analysis 9, 1-11.

Huisman, Ronald, Kees Koedijk, Clemens Kool and Francois Nissen (1998), "Extreme Support for Uncovered Interest Rate Parity”, Journal of International Money and Finance 17, 211-228.

Jahankhani, Ali (1976), "E-V and E-S Capital Asset Pricing Models: Some Empirical Tests", Journal of Financial and Quantitative Analysis 11, 513-528.

Kahneman, Daniel and Amos Tversky (1979), "Prospect Theory: An Analysis of Decision Under Risk", Econometrica 47, 263-291.

Lettau, Martin, Matteo Maggiori and Michael Weber (2013), "Conditional Risk Premia in Currency Markets and Other Asset Classes”, NBER Working Paper 18844. 
Lintner, John (1965), "The Valuation of Risk Assets and the Selection of Risky Investments in Stock Portfolios and Capital Budgets", Review of Economics and Statistics 47, 13-37.

Lothian, James R. and Liuren Wu (2005), "Uncovered Interest-Rate Parity over the Past Two Centuries", Working Paper.

Lustig, Hanno, Nikolai Roussanov and Adrien Verdelhan (2011), "Common Risk Factors in Currency Markets", Review of Financial Studies 24, 3731-3777.

Lustig, Hanno and Adrien Verdelhan (2006), "Investing In Foreign Currency Is Like Betting On Your Intertemporal Marginal Rate Of Substitution", Journal of the European Economic Association 4, 644-655.

Lustig, Hanno and Adrien Verdelhan (2007), "The Cross-section of Foreign Currency Risk Premia and U.S. Consumption Growth Risk", American Economic Review 97, 89-117.

Lustig, Hanno and Adrien Verdelhan (2011), "The Cross Section of Foreign Currency Risk Premia and Consumption Growth Risk: Reply”, American Economic Review 101, 3477-3500.

Markowitz, Harry (1959), "Portfolio Selection”, Yale University Press, New Haven, CT.

Menkhoff, Lukas, Lucio Sarno, Maik Schmeling and Andreas Schrimpf (2012a), "Carry Trades and Global Foreign Exchange Volatility", Journal of Finance 67, 681-718.

Menkhoff, Lukas, Lucio Sarno, Maik Schmeling and Andreas Schrimpf (2012b), "Currency Momentum Strategies”, Journal of Financial Economics 106, 620-684.

Meredith, Guy and Menzie D. Chinn (2005), "Testing Uncovered Interest Rate Parity at Short and Long Horizons during the Post-Bretton Woods Era”, NBER Working Paper 11077.

Ranaldo, Angelo and Paul Söderlind (2010), "Safe Haven Currencies", Review of Finance 14, 385-407.

Rafferty, Barry (2011), “Currency Returns, Skewness and Crash Risk”, Working Paper.

Reinhart, Carmen M. and Kenneth S. Rogoff (2004), "The Modern History of Exchange Rate Arrangements: A Reinterpretation", Quarterly Journal of Economics 119, 1-48.

Rubenstein, Mark (1976), "The Valuation of Uncertain Income Streams and the Price of Options", Bell Journal of Economics 7, 407-425.

Sharpe, William F. (1964), "Capital Asset Prices: A Theory of Market Equilibrium Under Conditions of Risk", Journal of Finance 19, 425-442.

Tryon, Ralph (1979), “Testing For Rational Expectations In Foreign Exchange Markets", International Finance Discussion Papers No. 139, Board of Governor's of the Federal Reserve System.

Verdelhan, Adrien (2010), "A Habit-Based Explanation of the Exchange Rate Risk Premium", Journal of Finance 55, 123-147. 
Verdelhan, Adrien (2012), "The Share of Systematic Risk in Bilateral Exchange Rates", Working Paper. 


\section{Tables}

Table 1: Overview of countries in sample and average currency excess return

\begin{tabular}{|c|c|c|c|}
\hline Developed & $\phi^{i}($ in $\%$ p.a. $)$ & Emerging & $\phi^{i}$ (in \% p.a.) \\
\hline \multirow[t]{2}{*}{ Australia } & 6.92 & Czech Republic & 0.71 \\
\hline & $(3.42)$ & & $(3.49)$ \\
\hline \multirow[t]{2}{*}{ Canada } & -1.01 & Hungary & 3.52 \\
\hline & $(2.38)$ & & $(4.03)$ \\
\hline \multirow[t]{2}{*}{ Euro Area } & 3.09 & India & 1.78 \\
\hline & $(2.80)$ & & $(1.88)$ \\
\hline \multirow[t]{2}{*}{ Japan } & 0.04 & Kuwait & 0.86 \\
\hline & $(2.60)$ & & $(1.13)$ \\
\hline \multirow[t]{2}{*}{ New Zealand } & 6.24 & Mexico & 4.33 \\
\hline & $(3.60)$ & & $(2.68)$ \\
\hline \multirow[t]{2}{*}{ Norway } & 1.49 & Philippines & -0.28 \\
\hline & $(3.01)$ & & $(1.81)$ \\
\hline \multirow[t]{2}{*}{ Singapore } & -0.50 & Poland & 0.48 \\
\hline & $(1.51)$ & & $(3.87)$ \\
\hline \multirow[t]{2}{*}{ Sweden } & 3.85 & South Africa & 7.71 \\
\hline & $(3.12)$ & & $(5.29)$ \\
\hline \multirow[t]{2}{*}{ Switzerland } & -4.01 & Thailand & -0.16 \\
\hline & $(2.95)$ & & $(1.93)$ \\
\hline \multirow[t]{2}{*}{ United Kingdom } & -1.39 & & \\
\hline & $(2.34)$ & & \\
\hline
\end{tabular}


Table 2: Baseline cross-sectional regression results

\begin{tabular}{|c|c|c|c|c|}
\hline \multicolumn{5}{|c|}{ Panel A: Standard CAPM } \\
\hline & $\lambda^{M}$ & $R^{2}$ & mspe & mape \\
\hline (I) & $\underset{(1.92)}{42.08}$ & 0.14 & 7.97 & 2.26 \\
\hline
\end{tabular}

Panel B: US-specific and global market return components

\begin{tabular}{|c|c|c|c|c|c|}
\hline & $\lambda^{\text {specific }}$ & $\lambda^{\text {global }}$ & $R^{2}$ & mspe & mape \\
\hline (II) & $\frac{-3.33}{(-0.71)}$ & $\underset{(1.91)}{40.27}$ & 0.45 & 4.89 & 1.85 \\
\hline
\end{tabular}

Panel C: Upside and downside states defined as positive or negative market return

\begin{tabular}{lccccccc}
\hline & $\lambda_{\text {up }}^{\text {specific }}$ & $\lambda_{\text {down }}^{\text {specific }}$ & $\lambda_{\text {up }}^{\text {global }}$ & $\lambda_{\text {down }}^{\text {global }}$ & $R^{2}$ & mspe & mape \\
(III) & $\underset{(1.35)}{6.05}$ & $\underset{(-1.37)}{-4.11}$ & $\underset{(-0.29)}{-2.75}$ & $\underset{(1.82)}{15.56}$ & 0.57 & 3.81 & 1.59
\end{tabular}

Panel D: Downside risk defined as market return one standard deviation below sample mean

\begin{tabular}{cccccccc}
\hline & $\lambda_{\text {up }}^{\text {specific }}$ & $\lambda_{\text {down }}^{\text {specific }}$ & $\lambda_{\text {up }}^{\text {global }}$ & $\lambda_{\text {down }}^{\text {global }}$ & $R^{2}$ & mspe & mape \\
(III) & $\underset{(-0.04)}{-016}$ & $\underset{(-1.37)}{-2.25}$ & $\underset{(1.07)}{14.84}$ & $\underset{(1.88)}{7.19}$ & 0.59 & 3.65 & 1.66
\end{tabular}

Notes: This table presents average risk price estimates (in \% p.a.), the measures of crosssectional fit, $R^{2}$, mean squared pricing errors and mean absolute pricing errors (both in \% p.a.) when using 19 bilateral currency excess returns as test assets in three CAPM variants over the sample period from January 1999 to March 2013. Shanken (1992) corrected $t$ statistics appear below the point estimates in parentheses.

The first model variant is the standard CAPM assuming that sensitivity to the US market return determines average currency excess returns (panel A). The second variant distinguishes between global and US-specific components in the market excess return (panel B) while the third empirical model additionally distinguishes between upside and downside states defined as positive (upside) or negative (downside) values of the market return (panel C). Finally, the fourth model variant defines downside states as periods with market return values below one standard deviation of its sample mean (panel D).

The cross-sectional regressions obey

$\phi_{t}^{i}=\lambda_{t}^{M} \hat{\beta}^{i, M}+v_{t}^{i}, \forall t$

$\phi_{t}^{i}=\lambda_{t}^{\text {specific }} \hat{\beta}^{i, \text { specific }}+\lambda_{t}^{\text {global }} \hat{\beta}^{i, \text { global }}+v_{t}^{i}, \forall t$.

$\phi_{t}^{i}=\lambda_{\text {up }, t}^{\text {specic }} \hat{\beta}_{\text {up }}^{i, \text { specific }}+\lambda_{\text {down }, t}^{\text {specific }} \hat{\beta}_{\text {down }}^{i, \text { specific }}+\lambda_{\text {up }, t}^{\text {global }} \hat{\beta}_{\text {up }}^{i, g l o b a l}+\lambda_{\text {down }, t}^{\text {global }} \hat{\beta}_{\text {down }}^{i, \text { global }}+v_{t}^{i}, \forall t$. 
Table 3: Estimates of sensitivities to market return components

(Conditional, bilateral currency excess returns)

\begin{tabular}{|c|c|c|c|c|}
\hline & $\widehat{\beta}_{u p}^{i, s p e c i f i c}$ & $\widehat{\beta}_{\text {down }}^{i, \text { specific }}$ & $\widehat{\beta}_{u p}^{i, g l o b a l}$ & $\widehat{\beta}_{\text {down }}^{i, \text { global }}$ \\
\hline Australia & $\begin{array}{l}0.01 \\
(0.27)\end{array}$ & $-\underset{(1.24)}{0.13}$ & $\begin{array}{l}0.09 \\
(0.11)\end{array}$ & $\begin{array}{l}0.38 \\
(0.26)\end{array}$ \\
\hline Canada & $\begin{array}{l}0.07 \\
(0.16)\end{array}$ & $-\underset{(0.69)}{0.66}$ & $\frac{-0.02}{(0.06)}$ & $-\underset{(0.18)}{-0.07}$ \\
\hline Czech Republic & ${ }_{(0.23)}^{0.10}$ & $-\underset{(0.88)}{2.06}$ & $\begin{array}{l}0.08 \\
(0.10)\end{array}$ & $-\underset{(0.26)}{0.39}$ \\
\hline Euro Area & $\begin{array}{c}-0.10 \\
(0.20)\end{array}$ & $\underset{(0.67)}{-1.04}$ & $\begin{array}{l}0.04 \\
(0.07)\end{array}$ & $\begin{array}{c}-0.14 \\
(0.20)\end{array}$ \\
\hline Hungary & -0.21 & -1.75 & $\begin{array}{l}0.09 \\
(0.12)\end{array}$ & $\begin{array}{c}-0.03 \\
(0.17)\end{array}$ \\
\hline India & $\begin{array}{c}-0.17 \\
(0.14)\end{array}$ & $\begin{array}{c}-0.63 \\
(0.35)\end{array}$ & $\begin{array}{l}0.02 \\
(0.07)\end{array}$ & $\begin{array}{c}-0.09 \\
(0.07)\end{array}$ \\
\hline Japan & $\begin{array}{l}0.43 \\
(0.23)\end{array}$ & $\underset{(0.46)}{-0.07}$ & $\begin{array}{l}0.07 \\
(0.07)\end{array}$ & $\begin{array}{l}0.12 \\
(0.16)\end{array}$ \\
\hline Kuwait & $\begin{array}{l}0.08 \\
(0.07)\end{array}$ & $\begin{array}{l}0.28 \\
(0.34)\end{array}$ & $\frac{-0.01}{(0.02)}$ & $\begin{array}{l}0.09 \\
(0.06)\end{array}$ \\
\hline Mexico & -0.01 & $\frac{-0.22}{(0.79)}$ & $\begin{array}{c}-0.03 \\
(0.07)\end{array}$ & $\underset{(0.23)}{0.10}$ \\
\hline New Zealand & $\begin{array}{l}0.14 \\
(0.22)\end{array}$ & $\underset{(1.16)}{-0.11}$ & $\underset{(0.10)}{0.14}$ & $\begin{array}{l}0.44 \\
(0.30)\end{array}$ \\
\hline Norway & $-\underset{(0.23)}{-0.46}$ & $\begin{array}{c}-0.88 \\
(0.58)\end{array}$ & $\underset{(0.09)}{-0.07}$ & $\begin{array}{l}0.35 \\
(0.13)\end{array}$ \\
\hline Philippines & $\begin{array}{c}-0.06 \\
(0.12)\end{array}$ & -0.15 & $-\underset{(0.04)}{-0.00}$ & $\begin{array}{l}0.02 \\
(0.16)\end{array}$ \\
\hline Poland & $\begin{array}{c}-0.29 \\
(0.30)\end{array}$ & -1.62 & $-\underset{(0.10)}{-0.00}$ & $\underset{(0.18)}{-0.36}$ \\
\hline Singapore & $\begin{array}{l}0.05 \\
(0.08)\end{array}$ & $\begin{array}{l}0.50 \\
(0.20)\end{array}$ & $\begin{array}{l}0.10 \\
(0.04)\end{array}$ & $\begin{array}{l}0.02 \\
(0.13)\end{array}$ \\
\hline South Africa & $\begin{array}{l}0.54 \\
(0.41)\end{array}$ & $-\underset{(0.96)}{2.60}$ & $\begin{array}{l}0.05 \\
(0.17)\end{array}$ & $\begin{array}{c}-0.05 \\
(0.18)\end{array}$ \\
\hline Sweden & -0.01 & $\underset{(0.88)}{-0.90}$ & $\begin{array}{l}0.08 \\
(0.09)\end{array}$ & -0.45 \\
\hline
\end{tabular}


Table 3 continued

\begin{tabular}{|c|c|c|c|c|}
\hline Switzerland & $\begin{array}{l}0.33 \\
(0.19)\end{array}$ & $\begin{array}{l}1.10 \\
(0.51)\end{array}$ & $\begin{array}{c}0.07 \\
(0.08)\end{array}$ & -0.10 \\
\hline Thailand & $\begin{array}{l}0.11 \\
(0.13)\end{array}$ & $-\underset{(0.24)}{0.37}$ & $\begin{array}{l}0.066 \\
(0.05)\end{array}$ & $\begin{array}{l}0.04 \\
(0.08)\end{array}$ \\
\hline United Kingdom & $-\underset{(0.14)}{-0.15}$ & $\begin{array}{c}-0.33 \\
(0.67)\end{array}$ & $\begin{array}{c}-0.03 \\
(0.07)\end{array}$ & $\begin{array}{c}-0.29 \\
(0.19)\end{array}$ \\
\hline \multicolumn{5}{|c|}{$\begin{array}{l}\text { Notes: This table provides estimates of the sensitivities of conditional, bilateral currency } \\
\text { excess returns to US-specific and global components of the US market return in upside and } \\
\text { downside states. A downside state is defined as periods with the market return being one } \\
\text { standard deviation below its sample average. If the market return is above this level, it is } \\
\text { considered to be an upside risk state. Newey-West (1987) corrected standard errors appear } \\
\text { below the estimates in parentheses. The sample period runs from January } 1999 \text { to March } \\
2013 \text {. }\end{array}$} \\
\hline
\end{tabular}


Table 4: Robustness Checks: The marginal explanatory power of downside risk

Panel A: Gauging the incremental impact of upside and downside risks

\begin{tabular}{cccccccc}
\hline & $\lambda_{\text {up }}^{\text {specific }}$ & $\lambda_{\text {down }}^{\text {specific }}$ & $\lambda_{\text {up }}^{\text {global }}$ & $\lambda_{\text {down }}^{\text {global }}$ & $R^{2}$ & mspe & mape \\
(I) & $1_{(0.27)}^{1.13}$ & $\underset{(-1.51)}{2.63}$ & $\underset{(0.60)}{8.49}$ & $\underset{(1.89)}{7.65}$ & 0.48 & 4.70 & 1.73
\end{tabular}

Panel B: Controlling for the level in global equity market volatility

\begin{tabular}{|c|c|c|c|c|c|c|c|}
\hline & $\lambda_{u p}^{\text {specific }}$ & $\lambda_{\text {down }}^{\text {specific }}$ & $\lambda_{u p}^{\text {global }}$ & $\lambda_{\text {down }}^{\text {global }}$ & $R^{2}$ & mspe & mape \\
\hline (II) & $\begin{array}{l}0.56 \\
(0.15)\end{array}$ & $\frac{-1.58}{(-0.98)}$ & $\frac{-0.16}{(-0.04)}$ & $\begin{array}{l}2.91 \\
(1.58)\end{array}$ & 0.48 & 4.65 & 1.80 \\
\hline \multicolumn{8}{|c|}{ Panel C: Controlling for changes in global equity market volatility } \\
\hline & $\lambda_{u p}^{\text {specific }}$ & $\lambda_{\text {down }}^{\text {specific }}$ & $\lambda_{u p}^{\text {global }}$ & $\lambda_{\text {down }}^{\text {global }}$ & $R^{2}$ & mspe & mape \\
\hline (III) & $\underset{(0.14)}{0.60}$ & -2.14 & $\underset{(0.91)}{11.82}$ & $\begin{array}{l}7.05 \\
(1.93)\end{array}$ & 0.59 & 3.66 & 1.66 \\
\hline
\end{tabular}

Notes: This table presents average risk price estimates (in \% p.a.), the measures of crosssectional fit, $R^{2}$, mean squared pricing errors and mean absolute pricing errors (both in \% p.a.) when using 19 bilateral, conditional currency excess returns as test assets in various specifications of a downside risk model over the sample period from January 1999 to March 2013. Shanken (1992) corrected $t$-statistics appear below the point estimates in parentheses.

Panel A gives the results when we examine the contribution of upside and downside risk on top of the unconditional sensitivity to the market return in upside and downside states. A downside state is defined as periods with the market return being one standard deviation below its sample average. If the market return is above this level, it is considered to be an upside risk state. Panel B presents estimates when controlling for exposure to the log of global equity market volatility. Global equity market volatility is calculated in two steps. First, we use daily returns to calculate the monthly standard deviation of the stock market indexes of the 19 countries in our sample. In the second step, we take the cross-sectional average of these volatility series each month. Panel $\mathrm{C}$ gives the corresponding results when we use changes instead of levels of global equity market volatility.

The cross-sectional regressions are specified as follows.

$$
\begin{aligned}
& \phi_{t}^{i}=\lambda_{u p, t}^{\text {specific }}\left(\hat{\beta}_{u p}^{i, \text { specific }}-\beta^{i, M}\right)+\lambda_{\text {down }, t}^{\text {specifi }}\left(\hat{\beta}_{\text {down }}^{i, \text { specific }}-\beta^{i, M}\right)+\lambda_{u p, t}^{\text {global }}\left(\hat{\beta}_{u p}^{i, \text { global }}-\beta^{i, M}\right) \\
& +\lambda_{\text {down }, t}^{\text {global }}\left(\hat{\beta}_{\text {down }}^{i, \text { global }}-\beta^{i, M}\right)+v_{t}^{i}, \forall t, \\
& \phi_{t}^{i}=\lambda_{u p, t}^{\text {specific }}\left(\hat{\beta}_{u p}^{i, \text { specific }}-\beta_{u p}^{i, \text { VOL }}\right)+\lambda_{\text {down }, t}^{\text {specif }}\left(\hat{\beta}_{\text {down }}^{i, \text { specific }}-\beta_{\text {down }}^{i, \text { VOL }}\right)+\lambda_{\text {up }, t}^{\text {global }}\left(\hat{\beta}_{u p}^{i, \text { global }}-\beta_{u p}^{i, \text { VOL }}\right) \\
& +\lambda_{\text {down }, t}^{\text {global }}\left(\hat{\beta}_{\text {down }}^{i, \text { global }}-\beta_{\text {down }}^{i, V O L}\right)+v_{t}^{i}, \forall t, \\
& \phi_{t}^{i}=\lambda_{u p, t}^{\text {specific }}\left(\hat{\beta}_{u p}^{i, \text { specific }}-\beta_{u p}^{i, \Delta V O L}\right)+\lambda_{\text {down }, t}^{\text {specifi }}\left(\hat{\beta}_{\text {down }}^{i, \text { specific }}-\beta_{\text {down }}^{i, \Delta V O L}\right)+\lambda_{u p, t}^{\text {global }}\left(\hat{\beta}_{u p}^{i, g l o b a l}-\beta_{u p}^{i, \Delta V O L}\right) \\
& +\lambda_{\text {down }, t}^{\text {global }}\left(\hat{\beta}_{\text {down }}^{i, \text { global }}-\beta_{\text {down }}^{i, \Delta V O L}\right)+v_{t}^{i}, \forall t
\end{aligned}
$$


Table 5: Robustness Checks: Country subsamples

\begin{tabular}{|c|c|c|c|c|c|c|c|}
\hline \multicolumn{8}{|c|}{ Panel A: Emerging markets } \\
\hline & $\lambda_{u p}^{\text {specific }}$ & $\lambda_{\text {down }}^{\text {specific }}$ & $\lambda_{u p}^{\text {global }}$ & $\lambda_{\text {down }}^{\text {global }}$ & $R^{2}$ & mspe & mape \\
\hline (I) & $\underset{(0.05)}{0.28}$ & $\begin{array}{c}-3.88 \\
(-1.49)\end{array}$ & -30.02 & $\underset{(1.55)}{14.13}$ & 0.89 & 0.70 & 0.72 \\
\hline
\end{tabular}

Panel B: Developed markets

\begin{tabular}{cccccccc}
\hline & $\lambda_{\text {up }}^{\text {specific }}$ & $\lambda_{\text {down }}^{\text {specific }}$ & $\lambda_{\text {up }}^{\text {global }}$ & $\lambda_{\text {down }}^{\text {global }}$ & $R^{2}$ & mspe & mape \\
(II) $\quad \operatorname{cccccc}_{(-0.95)}^{-4.81}$ & $\underset{(-1.19)}{2.50}$ & $\underset{(1.97)}{33.29}$ & $\underset{(1.23)}{4.39}$ & 0.85 & 2.19 & 1.30 \\
& & & & & & & \\
\hline
\end{tabular}

Panel C: Developed markets in the sample period January 1985 to March 2013

\begin{tabular}{cccccccc}
\hline & $\lambda_{\text {up }}^{\text {specific }}$ & $\lambda_{\text {down }}^{\text {specific }}$ & $\lambda_{\text {up }}^{\text {global }}$ & $\lambda_{\text {down }}^{\text {global }}$ & $R^{2}$ & mspe & mape \\
(III) & $\underbrace{14.08}_{(-1.02)}$ & $\underset{(-1.90)}{-6.25}$ & $\underset{(1.71)}{15.30}$ & $\underset{(0.05)}{0.21}$ & 0.85 & 1.15 & 0.84
\end{tabular}

Notes: This table presents average risk price estimates (in \% p.a.), the measures of crosssectional fit, $R^{2}$, mean squared pricing errors and mean absolute pricing errors (both in \% p.a.) when (I) using 9 bilateral, conditional currency excess returns of emerging markets over the sample period from January 1999 to March 2013, (II) using 10 bilateral, conditional currency excess returns of developed markets over the sample period from January 1999 to March 2013 and when (III) using 10 bilateral, conditional currency excess returns of developed markets over the sample period from January 1985 to March 2013 as test assets in cross-sectional regressions of the form

$\phi_{t}^{i}=\lambda_{\text {up }, t}^{\text {specific }} \hat{\beta}_{\text {up }}^{i, \text { specific }}+\lambda_{\text {down }, t}^{\text {specific }} \hat{\beta}_{\text {down }}^{i, \text { specific }}+\lambda_{\text {up }, t}^{\text {global }} \hat{\beta}_{\text {up }}^{i, g l o b a l}+\lambda_{\text {down }, t}^{\text {global }} \hat{\beta}_{\text {down }}^{i, g l o b a l}+v_{t}^{i}, \forall t$. 
Table 6: Estimates of sensitivities to market return components

(the negative of unconditional, log exchange rate changes)

\begin{tabular}{|c|c|c|c|c|}
\hline & $\widehat{\beta}_{u p}^{i, s p e c i f i c}$ & $\widehat{\beta}_{\text {down }}^{i \text { specific }}$ & $\widehat{\beta}_{u p}^{i, g l o b a l}$ & $\widehat{\beta}_{\text {down }}^{i, g l o b a l}$ \\
\hline Australia & $-\underset{(0.20)}{0.94}$ & -1.20 & $\begin{array}{l}0.57 \\
(0.06)\end{array}$ & $\begin{array}{l}0.66 \\
(0.23)\end{array}$ \\
\hline Canada & $\begin{array}{c}-0.49 \\
(0.15)\end{array}$ & $-\underset{(0.51)}{0.19}$ & $\begin{array}{l}0.38 \\
(0.06)\end{array}$ & $\begin{array}{l}0.49 \\
(0.22)\end{array}$ \\
\hline Czech Republic & -1.39 & $-{ }_{(0.63)}^{1.63}$ & $\begin{array}{l}0.45 \\
(0.08)\end{array}$ & $\begin{array}{l}0.33 \\
(0.15)\end{array}$ \\
\hline Euro Area & -1.12 & -1.30 & $\begin{array}{l}0.37 \\
(0.07)\end{array}$ & $\begin{array}{l}0.47 \\
(0.13)\end{array}$ \\
\hline Hungary & -1.21 & -1.95 & $\begin{array}{l}0.51 \\
(0.09)\end{array}$ & $\begin{array}{l}0.61 \\
(0.21)\end{array}$ \\
\hline India & $\begin{array}{c}-0.39 \\
(0.14)\end{array}$ & $\begin{array}{l}-0.84 \\
(0.35)\end{array}$ & $\begin{array}{l}0.22 \\
(0.05)\end{array}$ & $\begin{array}{l}0.19 \\
(0.09)\end{array}$ \\
\hline Japan & -0.40 & -0.12 & $\begin{array}{l}0.07 \\
(0.08)\end{array}$ & $\begin{array}{l}-0.09 \\
(0.32)\end{array}$ \\
\hline Kuwait & $-\underset{(0.03)}{0.11}$ & $\begin{array}{c}-0.15 \\
(0.09)\end{array}$ & $\begin{array}{l}0.03 \\
(0.02)\end{array}$ & $\underset{(0.03)}{0.11}$ \\
\hline Mexico & $\begin{array}{l}0.04 \\
(0.16)\end{array}$ & $\begin{array}{c}-0.43 \\
(0.79)\end{array}$ & $\begin{array}{l}0.32 \\
(0.06)\end{array}$ & $\underset{(0.21)}{0.62}$ \\
\hline New Zealand & $\begin{array}{c}-0.78 \\
(0.24)\end{array}$ & $\underset{(0.65)}{-1.54}$ & $\begin{array}{l}0.51 \\
(0.07)\end{array}$ & $\begin{array}{l}0.51 \\
(0.17)\end{array}$ \\
\hline Norway & $-\underset{(0.16)}{0.98}$ & -1.39 & $\begin{array}{l}0.41 \\
(0.07)\end{array}$ & $\begin{array}{l}0.58 \\
(0.18)\end{array}$ \\
\hline Philippines & $\begin{array}{c}-0.16 \\
(0.13)\end{array}$ & -0.56 & $\underset{(0.04)}{0.18}$ & $\begin{array}{l}0.23 \\
(0.09)\end{array}$ \\
\hline Poland & $\underset{(0.16)}{-1.11}$ & $\frac{-1.53}{(0.72)}$ & $\begin{array}{l}0.67 \\
(0.08)\end{array}$ & $\begin{array}{l}0.57 \\
(0.21)\end{array}$ \\
\hline Singapore & $-\underset{(0.12)}{0.35}$ & $\begin{array}{c}-0.66 \\
(0.32)\end{array}$ & $\begin{array}{l}0.19 \\
(0.03)\end{array}$ & $\begin{array}{l}0.18 \\
(0.08)\end{array}$ \\
\hline South Africa & $-\underset{(0.22)}{0.93}$ & $\underset{(0.42)}{-1.64}$ & $\begin{array}{l}0.54 \\
(0.10)\end{array}$ & $\begin{array}{l}0.51 \\
(0.22)\end{array}$ \\
\hline Sweden & $-\underset{(0.18)}{0.92}$ & $-{ }_{(0.40)}^{1.07}$ & $\begin{array}{l}0.53 \\
(0.06)\end{array}$ & $\begin{array}{l}0.55 \\
(0.13)\end{array}$ \\
\hline
\end{tabular}


Table 6 continued

\begin{tabular}{|c|c|c|c|c|}
\hline Switzerland & -1.21 & $-\frac{1.68}{(0.65)}$ & $\begin{array}{l}0.24 \\
(0.05)\end{array}$ & $\begin{array}{l}0.18 \\
(0.14)\end{array}$ \\
\hline Thailand & $-\underset{(0.22)}{0.33}$ & $-\underset{(0.27)}{0.41}$ & $\begin{array}{l}0.21 \\
(0.06)\end{array}$ & $\begin{array}{l}0.20 \\
(0.08)\end{array}$ \\
\hline United Kingdom & $\begin{array}{c}-0.88 \\
(0.17)\end{array}$ & $\begin{array}{c}-0.49 \\
(0.45)\end{array}$ & $\begin{array}{l}0.27 \\
(0.05)\end{array}$ & $\begin{array}{l}0.50 \\
(0.13)\end{array}$ \\
\hline \multicolumn{5}{|c|}{$\begin{array}{l}\text { Notes: This table provides estimates of the sensitivities of the negative of unconditional, log } \\
\text { exchange rate changes to US-specific and global components of the US market return in } \\
\text { upside and downside states. A downside state is defined as periods with the market return } \\
\text { being one standard deviation below its sample average. If the market return is above this } \\
\text { level, it is considered to be an upside risk state. Newey-West (1987) corrected standard errors } \\
\text { appear below the estimates in parentheses. The sample period runs from January } 1999 \text { to } \\
\text { March } 2013 \text {. }\end{array}$} \\
\hline
\end{tabular}


Table 7: Currency portfolios sorted by global downside risk beta

of unconditional exchange rate changes

Panel A: Full country sample

High beta $\quad$ Low beta High minus Low
Mean excess return
3.58
$-2.66$
6.24

(\% p.a.)

Panel B: Developed markets sample

High beta Low beta High minus Low
Mean excess return
3.83
$-1.65$
5.48

(\% p.a.)

Panel C: Emerging markets sample

High beta Low beta High minus Low

$\begin{array}{llll}\text { Mean excess return } & 3.65 & -4.81 & 8.46\end{array}$

(\% p.a.)

Notes: This table presents mean excess returns and standard errors of currency portfolios sorted according to the exposure of unconditional, log exchange rate changes to the global downside risk component of the US market return as presented in table 6 . The sample period runs from January 1999 to March 2013. We report excess returns on long positions in the high beta portfolios and short positions in the low beta portfolios. Standard errors of the mean returns are in parenthesis. In the full sample of countries (panel A), the high global downside risk beta portfolio comprises currencies of Australia, Hungary, Mexico, Norway and Poland. The low downside risk portfolio consists of currencies of India, Japan, Kuwait, Singapore and Switzerland. In the developed (panel B) and emerging markets sample (panel C), we use only three currencies to form the high and low global downside risk portfolios. In the case of the developed markets sample, the high beta portfolio contains currencies of Australia, New Zealand and Norway. The low global downside risk portfolio comprises currencies of Japan, Singapore and Switzerland. In the case of the emerging markets sample, the high beta portfolio comprises currencies of Hungary, Poland and Mexico. The low beta portfolio contains currencies of India, Kuwait and Thailand. 
Table 8: Estimates of sensitivities to market return components

(Conditional, bilateral currency excess returns; sample before crisis)

\begin{tabular}{|c|c|c|c|c|}
\hline & $\widehat{\beta}_{u p}^{i, s p e c i f i c}$ & $\widehat{\beta}_{\text {down }}^{i, \text { specific }}$ & $\widehat{\beta}_{u p}^{i, g l o b a l}$ & $\widehat{\beta}_{\text {down }}^{i, g \text { lobal }}$ \\
\hline Australia & $\begin{array}{c}-0.08 \\
(0.25)\end{array}$ & $\begin{array}{l}1.99 \\
(1.40)\end{array}$ & $\begin{array}{l}0.08 \\
(0.07)\end{array}$ & $\begin{array}{l}1.06 \\
(0.81)\end{array}$ \\
\hline Canada & $\begin{array}{l}0.08 \\
(0.17)\end{array}$ & $\begin{array}{l}0.39 \\
(0.36)\end{array}$ & $\begin{array}{l}0.01 \\
(0.06)\end{array}$ & $\begin{array}{l}0.29 \\
(0.28)\end{array}$ \\
\hline Czech Republic & $\begin{array}{l}0.31 \\
(0.27)\end{array}$ & $\begin{array}{l}0.31 \\
(0.46)\end{array}$ & $\begin{array}{l}0.11 \\
(0.09)\end{array}$ & $\begin{array}{l}0.38 \\
(0.24)\end{array}$ \\
\hline Euro Area & $\begin{array}{l}0.12 \\
(0.20)\end{array}$ & $\begin{array}{l}0.44 \\
(0.80)\end{array}$ & $\begin{array}{l}0.10 \\
(0.09)\end{array}$ & $\begin{array}{l}0.38 \\
(0.24)\end{array}$ \\
\hline Hungary & $\frac{-0.02}{(0.25)}$ & $\underset{(0.61)}{-1.45}$ & $\begin{array}{l}0.05 \\
(0.12)\end{array}$ & $\underset{(0.22)}{-0.41}$ \\
\hline India & $\underset{(0.10)}{-0.12}$ & $\underset{(0.10)}{-0.09}$ & $\begin{array}{l}0.05 \\
(0.03)\end{array}$ & $-\underset{(0.08)}{0.10}$ \\
\hline Japan & $\begin{array}{l}0.56 \\
(0.26)\end{array}$ & $\underset{(0.51)}{-0.02}$ & $\begin{array}{l}0.066 \\
(0.11)\end{array}$ & $-\underset{(0.45)}{0.46}$ \\
\hline Kuwait & $\begin{array}{c}-0.03 \\
(0.03)\end{array}$ & $\underset{(0.05)}{0.18}$ & $\underset{(0.02)}{-0.01}$ & $\begin{array}{c}-0.01 \\
(0.02)\end{array}$ \\
\hline Mexico & $\begin{array}{l}0.23 \\
(0.17)\end{array}$ & $\begin{array}{l}0.81 \\
(0.47)\end{array}$ & $\underset{(0.06)}{-0.11}$ & $\underset{(0.15)}{-0.35}$ \\
\hline New Zealand & $\begin{array}{l}0.01 \\
(0.23)\end{array}$ & $\underset{(1.60)}{1.32}$ & $\begin{array}{l}0.13 \\
(0.10)\end{array}$ & $\begin{array}{l}0.73 \\
(0.83)\end{array}$ \\
\hline Norway & $\underset{(0.23)}{-0.17}$ & $\underset{(0.36)}{-0.65}$ & $-{ }_{(0.11)}^{0.10}$ & $\begin{array}{l}0.10 \\
(0.15)\end{array}$ \\
\hline Philippines & $\underset{(0.13)}{-0.10}$ & $-\underset{(0.57)}{-1.01}$ & $\begin{array}{c}-0.02 \\
(0.05)\end{array}$ & $\begin{array}{c}-0.39 \\
(0.34)\end{array}$ \\
\hline Poland & $\underset{(0.35)}{-0.11}$ & $\begin{array}{c}-0.45 \\
(0.71)\end{array}$ & $\underset{(0.12)}{0.02}$ & $\underset{(0.19)}{-0.51}$ \\
\hline Singapore & $\begin{array}{l}0.11 \\
(0.09)\end{array}$ & $\begin{array}{l}0.60 \\
(0.16)\end{array}$ & $\begin{array}{l}0.02 \\
(0.05)\end{array}$ & $\begin{array}{l}0.10 \\
(0.20)\end{array}$ \\
\hline South Africa & $\begin{array}{l}0.66 \\
(0.66)\end{array}$ & $-\underset{(0.74)}{2.02}$ & $\begin{array}{l}0.06 \\
(0.22)\end{array}$ & $\begin{array}{c}-0.09 \\
(0.37)\end{array}$ \\
\hline Sweden & $\begin{array}{l}0.23 \\
(0.25)\end{array}$ & $\begin{array}{l}0.14 \\
(0.66)\end{array}$ & $\begin{array}{l}0.13 \\
(0.08)\end{array}$ & -0.01 \\
\hline
\end{tabular}


Table 8 continued

\begin{tabular}{|c|c|c|c|c|}
\hline Switzerland & $\begin{array}{l}0.28 \\
(0.17)\end{array}$ & $\begin{array}{l}1.90 \\
(0.82)\end{array}$ & $\begin{array}{l}0.10 \\
(0.12)\end{array}$ & $\begin{array}{l}0.53 \\
(0.52)\end{array}$ \\
\hline Thailand & $\begin{array}{l}0.17 \\
(0.19)\end{array}$ & $-\frac{0.05}{(0.26)}$ & $\begin{array}{l}0.00 \\
(0.06)\end{array}$ & $\begin{array}{l}0.00 \\
(0.20)\end{array}$ \\
\hline United Kingdom & $\underset{(0.17)}{-0.14}$ & $\begin{array}{l}0.70 \\
(0.75)\end{array}$ & $\begin{array}{l}0.09 \\
(-0.02)\end{array}$ & $\begin{array}{l}0.65 \\
(0.37)\end{array}$ \\
\hline \multicolumn{5}{|c|}{$\begin{array}{l}\text { Notes: This table provides estimates of the sensitivities of conditional, bilateral currency } \\
\text { excess returns to the US-specific and global risk components in upside and downside states. A } \\
\text { downside state is defined as periods with the market return being one standard deviation } \\
\text { below its sample average. If the market return is above this level, it is considered to be an } \\
\text { upside risk state. Newey-West (1987) corrected standard errors appear below the estimates in } \\
\text { parentheses. The sample period runs from January } 1999 \text { to June } 2007 \text {. }\end{array}$} \\
\hline
\end{tabular}


Table 9: Robustness Checks: Period before recent global financial crisis

\begin{tabular}{|c|c|c|c|c|c|c|}
\hline \multicolumn{7}{|c|}{ Panel A: Risk price estimates and measures of cross-sectional fit } \\
\hline$\lambda_{\text {up }}^{\text {specific }}$ & $\lambda_{\text {down }}^{\text {specific }}$ & $\lambda_{u p}^{\text {global }}$ & $\lambda_{\text {down }}^{\text {global }}$ & $R^{2}$ & mspe & mape \\
\hline $\begin{array}{l}8.38 \\
(1.85)\end{array}$ & $\begin{array}{c}-2.79 \\
(-1.36)\end{array}$ & $\underset{(1.71)}{19.74}$ & $\underset{(1.51)}{6.15}$ & 0.26 & 17.28 & 3.24 \\
\hline \multicolumn{7}{|c|}{ Panel B: Portfolios sorted by global downside beta: full country sample } \\
\hline & ( $\underline{\mathrm{H}) \text { igh }}$ & & $\underline{\text { (L)ow }}$ & & $\underline{\mathrm{H}-\mathrm{L}}$ & \\
\hline Mean & 2.17 & & -7.16 & & 9.32 & \\
\hline (standard & $(2.42)$ & & $(3.07)$ & & $(5.03)$ & \\
\hline \multicolumn{7}{|l|}{ error) } \\
\hline \multicolumn{7}{|c|}{ Panel C: Portfolios sorted by global downside beta: developed markets } \\
\hline & $\underline{(\mathrm{H}) \text { igh }}$ & & (L)ow & & $\underline{\mathrm{H}-\mathrm{L}}$ & \\
\hline Mean & -1.43 & & -6.20 & & 4.78 & \\
\hline (standard & $(1.94)$ & & $(3.14)$ & & $(4.64)$ & \\
\hline error) & & & & & & \\
\hline
\end{tabular}

Panel D: Portfolios sorted by global downside beta: emerging markets

\begin{tabular}{cccc}
\hline & $\underline{(\mathrm{H}) \text { igh }}$ & $\underline{(\mathrm{L}) \mathrm{ow}}$ & $\underline{\mathrm{H}-\mathrm{L}}$ \\
Mean & 5.33 & -8.00 & 13.32 \\
(standard & $(2.07)$ & $(2.53)$ & $(3.86)$ \\
error $)$ & & &
\end{tabular}

Notes: Panel A of this table presents average risk price estimates (in \% p.a.), the measures of cross-sectional fit, $R^{2}$, mean squared pricing errors and mean absolute pricing errors (both in $\%$ p.a.) when using 19 bilateral, conditional currency excess returns as test assets in our baseline specification of the downside risk model over the sample period from January 1999 to June 2007. Shanken (1992) corrected $t$-statistics appear below the point estimates in parentheses.

Panels B to D of this table present mean excess returns and standard errors of currency portfolios that are sorted according to the exposure of unconditional, log exchange rate changes to the global downside risk component of the US market return as presented in table 10. The sample period runs form January 1999 to June 2007. We report excess returns on long positions in the high beta portfolios and short positions in the low beta portfolios. Standard errors of the mean returns are in parenthesis. In the full sample of countries (panel B), the 
high global downside risk beta portfolio comprises currencies of Japan, Singapore, South Africa, Thailand and the UK. The low downside risk portfolio consists of currencies of Australia, Czech Republic, Hungary, New Zealand and Sweden. In the developed (panel C) markets sample, we use only three currencies to form the high and low global downside risk portfolios. In the case of the developed markets sample, the high beta portfolio contains currencies of Japan, Singapore and the UK. The low global downside risk portfolio comprises currencies of Australia, New Zealand and Sweden. In the case of the emerging markets sample, the high beta portfolio comprises four currencies because Kuwait and Mexico have the same exposure to global downside risk. The other two currencies in the high beta portfolio are South Africa and Thailand. The low beta portfolio contains currencies of Czech Republic, Hungary and the Philippines. 
Table 10: Estimates of sensitivities to market return components

(the negative of unconditional, log exchange rate changes; pre-crisis period)

\begin{tabular}{|c|c|c|c|c|}
\hline & $\widehat{\beta}_{u p}^{i, s p e c i f i c}$ & $\widehat{\beta}_{\text {down }}^{i, \text { specific }}$ & $\widehat{\beta}_{u p}^{i, g l o b a l}$ & $\widehat{\beta}_{\text {down }}^{i, g l o b a l}$ \\
\hline Australia & $-\underset{(0.22)}{0.69}$ & $\begin{array}{c}-2.09 \\
(0.49)\end{array}$ & $\begin{array}{l}0.36 \\
(0.07)\end{array}$ & $-\underset{(0.11)}{0.16}$ \\
\hline Canada & $\underset{(0.12)}{-0.28}$ & $-\underset{(0.35)}{0.73}$ & $\begin{array}{l}0.19 \\
(0.05)\end{array}$ & $\begin{array}{l}0.13 \\
(0.15)\end{array}$ \\
\hline Czech Republic & -1.35 & $-\underset{(0.30)}{2.36}$ & $\begin{array}{l}0.21 \\
(0.08)\end{array}$ & $\underset{(0.17)}{-0.26}$ \\
\hline Euro Area & $-{ }_{(0.25)}^{1.07}$ & $-\underset{(0.38)}{1.73}$ & $\begin{array}{l}0.18 \\
(0.06)\end{array}$ & $-0_{(0.22)}^{0.10}$ \\
\hline Hungary & $--_{(0.31)}^{1.01}$ & -1.67 & $\begin{array}{l}0.24 \\
(0.08)\end{array}$ & $\begin{array}{c}-0.17 \\
(0.20)\end{array}$ \\
\hline India & $-\underset{(0.09)}{-0.21}$ & $\underset{(0.07)}{-0.14}$ & $\begin{array}{l}0.13 \\
(0.04)\end{array}$ & $\frac{-0.02}{(0.03)}$ \\
\hline Japan & $\underset{(0.35)}{-0.43}$ & -1.28 & $\begin{array}{l}0.17 \\
(0.10)\end{array}$ & $\underset{(0.31)}{0.17}$ \\
\hline Kuwait & $\begin{array}{c}-0.09 \\
(0.04)\end{array}$ & $\frac{-0.18}{(0.05)}$ & -0.00 & $\begin{array}{l}0.03 \\
(0.03)\end{array}$ \\
\hline Mexico & $\underset{(0.20)}{0.01}$ & $\begin{array}{l}0.40 \\
(0.65)\end{array}$ & $\begin{array}{l}0.18 \\
(0.07)\end{array}$ & $\begin{array}{l}0.03 \\
(0.29)\end{array}$ \\
\hline New Zealand & $\begin{array}{c}-0.62 \\
(0.31)\end{array}$ & -2.93 & $\begin{array}{l}0.32 \\
(0.08)\end{array}$ & $\begin{array}{c}-0.33 \\
(0.19)\end{array}$ \\
\hline Norway & $-\underset{(0.22)}{0.96}$ & $-\underset{(0.33)}{1.71}$ & $\begin{array}{l}0.19 \\
(0.08)\end{array}$ & $-\underset{(0.18)}{-0.07}$ \\
\hline Philippines & $\begin{array}{l}0.01 \\
(0.15)\end{array}$ & $\underset{(0.52)}{-1.14}$ & $\begin{array}{l}0.13 \\
(0.07)\end{array}$ & $-\underset{(0.23)}{0.14}$ \\
\hline Poland & $\frac{-1.06}{(0.19)}$ & $\underset{(0.46)}{-1.44}$ & $\begin{array}{l}0.53 \\
(0.09)\end{array}$ & $-\underset{(0.21)}{0.07}$ \\
\hline Singapore & $-\underset{(0.13)}{0.22}$ & $\begin{array}{c}-0.75 \\
(0.43)\end{array}$ & $\begin{array}{l}0.10 \\
(0.04)\end{array}$ & $\begin{array}{l}0.16 \\
(0.19)\end{array}$ \\
\hline South Africa & -1.21 & $\underset{(0.63)}{-1.06}$ & $\begin{array}{l}0.35 \\
(0.15)\end{array}$ & $\begin{array}{l}0.20 \\
(0.31)\end{array}$ \\
\hline Sweden & -1.00 & -1.78 & $\begin{array}{l}0.31 \\
(0.07)\end{array}$ & -0.25 \\
\hline
\end{tabular}




\section{Table 10 continued}

\begin{tabular}{|c|c|c|c|c|}
\hline Switzerland & $-{ }_{(0.27)}$ & $-{ }_{(0.52)}$ & $\begin{array}{l}0.09 \\
(0.07)\end{array}$ & $\begin{array}{c}-0.08 \\
(0.27)\end{array}$ \\
\hline Thailand & $-\underset{(0.27)}{0.23}$ & $-\underset{(0.38)}{0.71}$ & $\begin{array}{l}0.25 \\
(0.09)\end{array}$ & $\begin{array}{l}0.19 \\
(0.15)\end{array}$ \\
\hline United Kingdom & $-\frac{0.82}{(0.23)}$ & $\underset{(0.30)}{-0.01}$ & $\begin{array}{l}0.16 \\
(0.07)\end{array}$ & $\begin{array}{l}0.23 \\
(0.16)\end{array}$ \\
\hline
\end{tabular}

Notes: This table provides estimates of the sensitivities of the negative of unconditional, $\log$ exchange rate changes to the US-specific and global risk components in upside and downside states of the US market return. A downside state is defined as periods with the market return being one standard deviation below its sample average. If the market return is above this level, it is considered to be an upside risk state. Newey-West (1987) corrected standard errors appear below the estimates in parenthesis. The sample period runs from January 1999 to June 2007. 


\section{Figures}

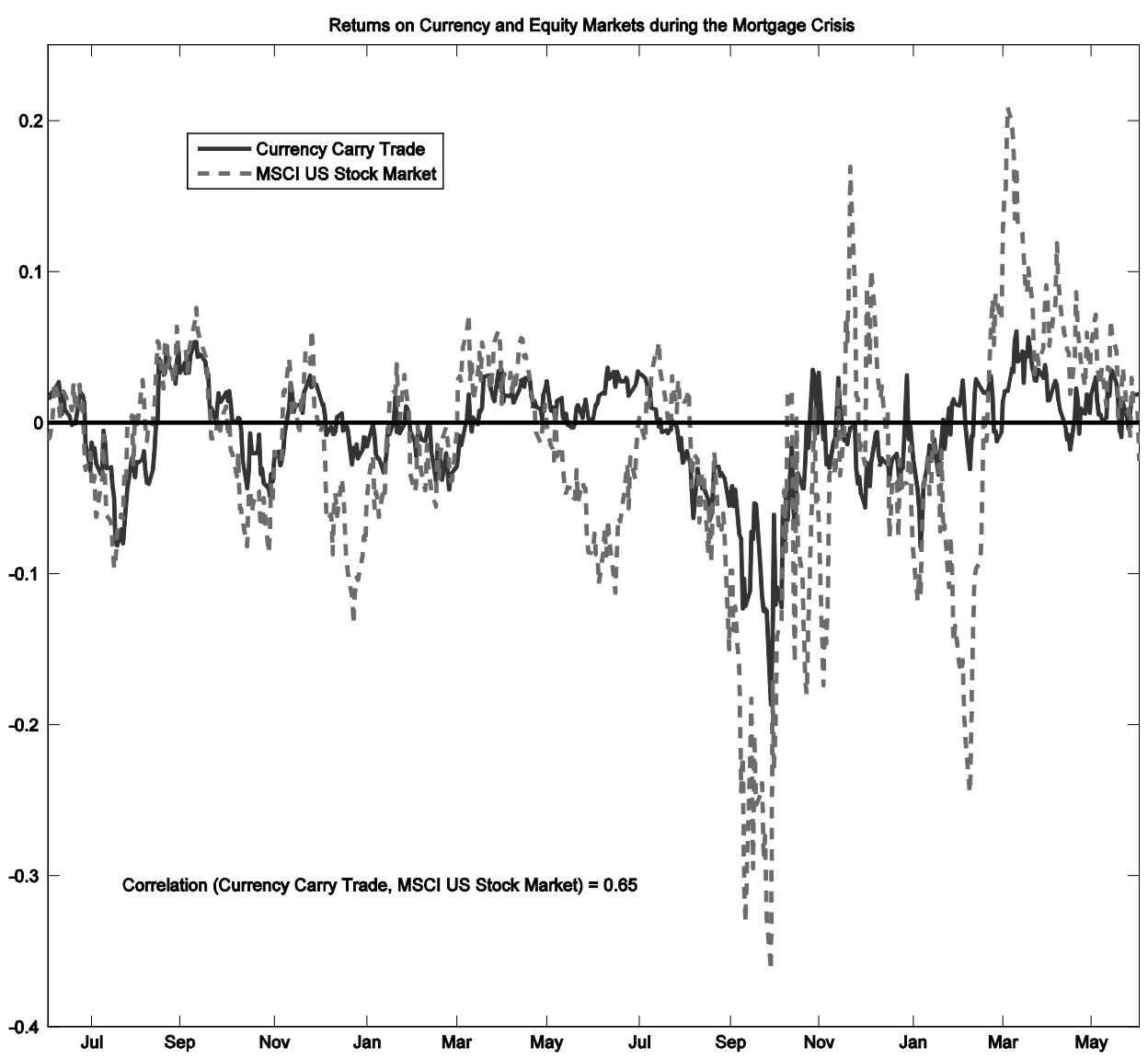

Figure 1: Correlation between a currency carry trade strategy (long position in high forward discount currencies and short position in low forward discount currencies) and the US stock market return during June 2007 to May 2009.

Source: Lustig and Verdelhan (2011) 


\section{Swiss National Bank Working Papers published since 2004:}

2004-1 Samuel Reynard: Financial Market Participation and the Apparent Instability of Money Demand

2004-2 Urs W. Birchler and Diana Hancock: What Does the Yield on Subordinated Bank Debt Measure?

2005-1 Hasan Bakhshi, Hashmat Khan and Barbara Rudolf: The Phillips curve under state-dependent pricing

2005-2 Andreas M. Fischer: On the Inadequacy of Newswire Reports for Empirical Research on Foreign Exchange Interventions

2006-1 Andreas M. Fischer: Measuring Income Elasticity for Swiss Money Demand: What do the Cantons say about Financial Innovation?

2006-2 Charlotte Christiansen and Angelo Ranaldo: Realized Bond-Stock Correlation: Macroeconomic Announcement Effects

2006-3 Martin Brown and Christian Zehnder: Credit Reporting, Relationship Banking, and Loan Repayment

2006-4 Hansjörg Lehmann and Michael Manz: The Exposure of Swiss Banks to Macroeconomic Shocks - an Empirical Investigation

2006-5 Katrin Assenmacher-Wesche and Stefan Gerlach: Money Growth, Output Gaps and Inflation at Low and High Frequency: Spectral Estimates for Switzerland

2006-6 Marlene Amstad and Andreas M. Fischer: Time-Varying Pass-Through from Import Prices to Consumer Prices: Evidence from an Event Study with Real-Time Data

2006-7 Samuel Reynard: Money and the Great Disinflation

2006-8 Urs W. Birchler and Matteo Facchinetti: Can bank supervisors rely on market data? A critical assessment from a Swiss perspective

2006-9 Petra Gerlach-Kristen: A Two-Pillar Phillips Curve for Switzerland

2006-10 Kevin J. Fox and Mathias Zurlinden: On Understanding Sources of Growth and Output Gaps for Switzerland

2006-11 Angelo Ranaldo: Intraday Market Dynamics Around Public Information Arrivals

2007-1 Andreas M. Fischer, Gulzina Isakova and Ulan Termechikov: Do FX traders in Bishkek have similar perceptions to their London colleagues? Survey evidence of market practitioners' views 
2007-2 Ibrahim Chowdhury and Andreas Schabert: Federal Reserve Policy viewed through a Money Supply Lens

2007-3 Angelo Ranaldo: Segmentation and Time-of-Day Patterns in Foreign Exchange Markets

2007-4 Jürg M. Blum: Why `Basel II' May Need a Leverage Ratio Restriction

2007-5 Samuel Reynard: Maintaining Low Inflation: Money, Interest Rates, and Policy Stance

2007-6 Rina Rosenblatt-Wisch: Loss Aversion in Aggregate Macroeconomic Time Series

2007-7 Martin Brown, Maria Rueda Maurer, Tamara Pak and Nurlanbek Tynaev: Banking Sector Reform and Interest Rates in Transition Economies: Bank-Level Evidence from Kyrgyzstan

2007-8 Hans-Jürg Büttler: An Orthogonal Polynomial Approach to Estimate the Term Structure of Interest Rates

2007-9 Raphael Auer: The Colonial Origins Of Comparative Development: Comment. A Solution to the Settler Mortality Debate

2007-10 Franziska Bignasca and Enzo Rossi: Applying the Hirose-Kamada filter to Swiss data: Output gap and exchange rate pass-through estimates

2007-11 Angelo Ranaldo and Enzo Rossi: The reaction of asset markets to Swiss National Bank communication

2007-12 Lukas Burkhard and Andreas M. Fischer: Communicating Policy Options at the Zero Bound

2007-13 Katrin Assenmacher-Wesche, Stefan Gerlach, and Toshitaka Sekine: Monetary Factors and Inflation in Japan

2007-14 Jean-Marc Natal and Nicolas Stoffels: Globalization, markups and the natural rate of interest

2007-15 Martin Brown, Tullio Jappelli and Marco Pagano: Information Sharing and Credit: Firm-Level Evidence from Transition Countries

2007-16 Andreas M. Fischer, Matthias Lutz and Manuel Wälti: Who Prices Locally? Survey Evidence of Swiss Exporters

2007-17 Angelo Ranaldo and Paul Söderlind: Safe Haven Currencies 
2008-1 Martin Brown and Christian Zehnder: The Emergence of Information Sharing in Credit Markets

2008-2 Yvan Lengwiler and Carlos Lenz: Intelligible Factors for the Yield Curve

2008-3 Katrin Assenmacher-Wesche and M. Hashem Pesaran: Forecasting the Swiss Economy Using VECX* Models: An Exercise in Forecast Combination Across Models and Observation Windows

2008-4 Maria Clara Rueda Maurer: Foreign bank entry, institutional development and credit access: firm-level evidence from 22 transition countries

2008-5 Marlene Amstad and Andreas M. Fischer: Are Weekly Inflation Forecasts Informative?

2008-6 Raphael Auer and Thomas Chaney: Cost Pass Through in a Competitive Model of Pricing-to-Market

2008-7 Martin Brown, Armin Falk and Ernst Fehr: Competition and Relational Contracts: The Role of Unemployment as a Disciplinary Device

2008-8 Raphael Auer: The Colonial and Geographic Origins of Comparative Development

2008-9 Andreas M. Fischer and Angelo Ranaldo: Does FOMC News Increase Global FX Trading?

2008-10 Charlotte Christiansen and Angelo Ranaldo: Extreme Coexceedances in New EU Member States' Stock Markets

2008-11 Barbara Rudolf and Mathias Zurlinden: Measuring capital stocks and capital services in Switzerland

2008-12 Philip Sauré: How to Use Industrial Policy to Sustain Trade Agreements

2008-13 Thomas Bolli and Mathias Zurlinden: Measuring growth of labour quality and the quality-adjusted unemployment rate in Switzerland

2008-14 Samuel Reynard: What Drives the Swiss Franc?

2008-15 Daniel Kaufmann: Price-Setting Behaviour in Switzerland - Evidence from CPI Micro Data

2008-16 Katrin Assenmacher-Wesche and Stefan Gerlach: Financial Structure and the Impact of Monetary Policy on Asset Prices

2008-17 Ernst Fehr, Martin Brown and Christian Zehnder: On Reputation: A Microfoundation of Contract Enforcement and Price Rigidity 
2008-18 Raphael Auer and Andreas M. Fischer: The Effect of Low-Wage Import Competition on U.S. Inflationary Pressure

2008-19 Christian Beer, Steven Ongena and Marcel Peter: Borrowing in Foreign Currency: Austrian Households as Carry Traders

2009-1 Thomas Bolli and Mathias Zurlinden: Measurement of labor quality growth caused by unobservable characteristics

2009-2 Martin Brown, Steven Ongena and Pinar Yeșin: Foreign Currency Borrowing by Small Firms

2009-3 Matteo Bonato, Massimiliano Caporin and Angelo Ranaldo: Forecasting realized (co)variances with a block structure Wishart autoregressive model

2009-4 Paul Söderlind: Inflation Risk Premia and Survey Evidence on Macroeconomic Uncertainty

2009-5 Christian Hott: Explaining House Price Fluctuations

2009-6 Sarah M. Lein and Eva Köberl: Capacity Utilisation, Constraints and Price Adjustments under the Microscope

2009-7 Philipp Haene and Andy Sturm: Optimal Central Counterparty Risk Management

2009-8 Christian Hott: Banks and Real Estate Prices

2009-9 Terhi Jokipii and Alistair Milne: Bank Capital Buffer and Risk Adjustment Decisions

2009-10 Philip Sauré: Bounded Love of Variety and Patterns of Trade

2009-11 Nicole Allenspach: Banking and Transparency: Is More Information Always Better?

2009-12 Philip Sauré and Hosny Zoabi: Effects of Trade on Female Labor Force Participation

2009-13 Barbara Rudolf and Mathias Zurlinden: Productivity and economic growth in Switzerland 1991-2005

2009-14 Sébastien Kraenzlin and Martin Schlegel: Bidding Behavior in the SNB's Repo Auctions

2009-15 Martin Schlegel and Sébastien Kraenzlin: Demand for Reserves and the Central Bank's Management of Interest Rates

2009-16 Carlos Lenz and Marcel Savioz: Monetary determinants of the Swiss franc 
2010-1 Charlotte Christiansen, Angelo Ranaldo and Paul Söderlind: The Time-Varying Systematic Risk of Carry Trade Strategies

2010-2 Daniel Kaufmann: The Timing of Price Changes and the Role of Heterogeneity

2010-3 Loriano Mancini, Angelo Ranaldo and Jan Wrampelmeyer: Liquidity in the Foreign Exchange Market: Measurement, Commonality, and Risk Premiums

2010-4 Samuel Reynard and Andreas Schabert: Modeling Monetary Policy

2010-5 Pierre Monnin and Terhi Jokipii: The Impact of Banking Sector Stability on the Real Economy

2010-6 Sébastien Kraenzlin and Thomas Nellen: Daytime is money

2010-7 Philip Sauré: Overreporting 0il Reserves

2010-8 Elizabeth Steiner: Estimating a stock-flow model for the Swiss housing market

2010-9 Martin Brown, Steven Ongena, Alexander Popov, and Pinar Yeșin: Who Needs Credit and Who Gets Credit in Eastern Europe?

2010-10 Jean-Pierre Danthine and André Kurmann: The Business Cycle Implications of Reciprocity in Labor Relations

2010-11 Thomas Nitschka: Momentum in stock market returns: Implications for risk premia on foreign currencies

2010-12 Petra Gerlach-Kristen and Barbara Rudolf: Macroeconomic and interest rate volatility under alternative monetary operating procedures

2010-13 Raphael Auer: Consumer Heterogeneity and the Impact of Trade Liberalization: How Representative is the Representative Agent Framework?

2010-14 Tommaso Mancini Griffoli and Angelo Ranaldo: Limits to arbitrage during the crisis: funding liquidity constraints and covered interest parity

2010-15 Jean-Marc Natal: Monetary Policy Response to Oil Price Shocks

2010-16 Kathrin Degen and Andreas M. Fischer: Immigration and Swiss House Prices

2010-17 Andreas M. Fischer: Immigration and large banknotes

2010-18 Raphael Auer: Are Imports from Rich Nations Deskilling Emerging Economies? Human Capital and the Dynamic Effects of Trade 
2010-19 Jean-Pierre Danthine and John B. Donaldson: Executive Compensation: A General Equilibrium Perspective

2011-1 Thorsten Beck and Martin Brown: Which Households Use Banks? Evidence from the Transition Economies

2011-2 Martin Brown, Karolin Kirschenmann and Steven Ongena: Foreign Currency Loans Demand or Supply Driven?

2011-3 Victoria Galsband and Thomas Nitschka: Foreign currency returns and systematic risks

2011-4 Francis Breedon and Angelo Ranaldo: Intraday patterns in FX returns and order flow

2011-5 Basil Guggenheim, Sébastien Kraenzlin and Silvio Schumacher: Exploring an uncharted market: Evidence on the unsecured Swiss franc money market

2011-6 Pamela Hall: Is there any evidence of a Greenspan put?

2011-7 Daniel Kaufmann and Sarah Lein: Sectoral Inflation Dynamics, Idiosyncratic Shocks and Monetary Policy

2011-8 Iva Cecchin: Mortgage Rate Pass-Through in Switzerland

2011-9 Raphael A. Auer, Kathrin Degen and Andreas M. Fischer: Low-Wage Import Competition, Inflationary Pressure, and Industry Dynamics in Europe

2011-10 Raphael A. Auer and Philip Sauré: Spatial Competition in Quality, Demand-Induced Innovation, and Schumpeterian Growth

2011-11 Massimiliano Caporin , Angelo Ranaldo and Paolo Santucci de Magistris: On the Predictability of Stock Prices: a Case for High and Low Prices

2011-12 Jürg Mägerle and Thomas Nellen: Interoperability between central counterparties

2011-13 Sylvia Kaufmann: K-state switching models with endogenous transition distributions

2011-14 Sébastien Kraenzlin and Benedikt von Scarpatetti: Bargaining Power in the Repo Market

2012-01 Raphael A. Auer: Exchange Rate Pass-Through, Domestic Competition, and Inflation: Evidence from the 2005/08 Revaluation of the Renminbi

2012-02 Signe Krogstrup, Samuel Reynard and Barbara Sutter: Liquidity Effects of Quantitative Easing on Long-Term Interest Rates 
2012-03 Matteo Bonato, Massimiliano Caporin and Angelo Ranaldo: Risk spillovers in international equity portfolios

2012-04 Thomas Nitschka: Banking sectors' international interconnectedness: Implications for consumption risk sharing in Europe

2012-05 Martin Brown, Steven Ongena and Pinar Yeşin: Information Asymmetry and Foreign Currency Borrowing by Small Firms

2012-06 Philip Sauré and Hosny Zoabi: Retirement Age across Countries: The Role of Occupations

2012-07 Christian Hott and Terhi Jokipii: Housing Bubbles and Interest Rates

2012-08 Romain Baeriswyl and Camille Cornand: Reducing overreaction to central bank's disclosures: theory and experiment

2012-09 Bo E. Honoré, Daniel Kaufmann and Sarah Lein: Asymmetries in Price-Setting Behavior: New Microeconometric Evidence from Switzerland

2012-10 Thomas Nitschka: Global and country-specific business cycle risk in time-varying excess returns on asset markets

2012-11 Raphael A. Auer, Thomas Chaney and Philip Sauré: Quality Pricing-to-Market

2012-12 Sébastien Kraenzlin and Thomas Nellen: Access policy and money market segmentation

2012-13 Andreas Kropf and Philip Sauré: Fixed Costs per Shipment

2012-14 Raphael A. Auer and Raphael S. Schoenle: Market Structure and Exchange Rate Pass-Through

2012-15 Raphael A. Auer: What Drives Target2 Balances? Evidence From a Panel Analysis

2012-16 Katja Drechsel and Rolf Scheufele: Bottom-up or Direct? Forecasting German GDP in a Data-rich Environment

2013-01 Andreas Kettemann and Signe Krogstrup: Portfolio balance effects of the SNB's bond purchase program

2013-02 Nicole Aregger, Martin Brown and Enzo Rossi: Transaction Taxes, Capital Gains Taxes and House Prices

2013-03 Simone Meier: Financial Globalization and Monetary Transmission 
2013-04 Christian Grisse and Thomas Nitschka: On financial risk and the safe haven characteristics of Swiss franc exchange rates

2013-05 Matthias Gubler and Matthias S. Hertweck: Commodity Price Shocks and the Business Cycle: Structural Evidence for the U.S.

2013-06 Elisabeth Beusch, Barbara Döbeli, Andreas Fischer and Pınar Yeşin: Merchanting and Current Account Balances

2013-07 Victoria Galsband and Thomas Nitschka: Currency excess returns and global downside market risk 
Swiss National Bank Working Papers are also available at www.snb.ch, section Publications/Research Subscriptions or individual issues can be ordered at Swiss National Bank, Fraumünsterstrasse 8, CH-8022 Zurich, fax +41 4463181 14, E-mail library@snb.ch 